\title{
Trade Liberalization in APEC and Global Value Chain Participation: What Can Value Added Indicators Tell?
}

\author{
Dorothee Flaig ${ }^{1+}$ and Jared Greenville ${ }^{2}$ \\ ${ }^{1}$ Hohenheim University, Germany \\ ${ }^{2}$ Australian Bureau of Agricultural and Resource Economics and Sciences, Australia
}

\begin{abstract}
Global value chains (GVCs) are an increasingly important driver of world trade, and they are relevant in analyzing border policies and trade agreements. Combining methods of value added decomposition and a computable general equilibrium model, we show how tariff liberalization in APEC impacts on measures of integration. The trade agreement increases GVC integration worldwide irrespective of membership. The effects differ by type of integration, namely, forward or backward, depending on the source of intermediate inputs, the membership of countries up- and downstream the supply chain, and the border protection in the base. The analysis reveals some limitations of the presented integration measures in a dynamic context. First, value added incorporates income related to policy measures, and decreasing integration can reflect a lower tax burden and a more efficient network. Second, changes do not allow interpreting the size of effects of underlying variables, and similar changes can result from various underlying developments.
\end{abstract}

Keywords: GVCs, Value added indicators, trade agreement, APEC

JEL Classifications: F13, F15, C68, O53

Received 14 December 2020, Revised 6 April 2021, Accepted 7 April 2021

\section{Introduction}

The manner in which trade is occurring has been evolving. A most notable development is the international fragmentation of countries as countries and industries are increasingly contributing elements to a final product rather than completing the production activity solely within domestic boundaries. Underpinning these changes have been advances in technology and logistics performance facilitating the breakup of economic activity (Baldwin, 2012, 2016). International production networks, commonly described as global value chains (GVCs), thus extend beyond the bilateral trading relationships that may be observed between two countries and that are often the focus of policymakers and commentators (see, e.g., OECD, 2013; de Backer and Mirodout, 2013;

\footnotetext{
+Corresponding Author: Dorothee Flaig

Researcher, International Agricultural Trade and Food Security, Hohenheim University, 70593 Stuttgart, Germany. Email: dorothee.flaig@uni-hohenheim.de

Co-Author: Jared Greenville

Acting Executive Director, ABARES - Australian Bureau of Agricultural and Resource Economics and Sciences, Department of Agriculture, Water and the Environment, GPO Box 858, Canberra City ACT 2601, Australia. Email: Jared.Greenville@awe.gov.au
} 
Balié et al., 2019). This has important implications for the situation reflected by trade balances (Johnson \& Noguera, 2012), and interventions restricting the movement of products across borders (or market investments) can be even more disruptive to domestic economies as barriers are magnified along GVCs (Koopman et al., 2010). Thus, trade policies (tariffs) are the key determinants of GVC integration in the food sector (Balié et al., 2019). In general, GVC integration is an essential factor underlying trade liberalization (Bureau et al., 2019). In addition, own import tariffs depress domestic value added (VA) that is returning home. Disruptive effects can negatively affect the incentives or abilities for the adoption of new production techniques, with implications for productivity (OECD, 2013).

Given the importance of GVC integration for productivity and effectiveness of policy instruments, the effect on GVC integration is relevant for the analysis of border policies and trade agreements. Various measures have been established that describe GVC integration. Widely used is an indicator of "vertical specialization" (Hummels et al., 2001, Koopman et al., 2010, 2014). Technically this indicator is translating gross trade flows into VA flows, disentangling where VA was originally created. Thus, the indicator describes the participation in a GVC as the combination of a backward-looking and forward-looking part. The backward-looking part shows the extent to which other countries' imports are used in the production of a country's exports, whereas the forward-looking part presents the extent to which a country's exports form part of a production process in another country, contributing to that other country's exports.

Changes in GVC integration depicted by this indicator result from complex endogenous relationships between output, reliant on the employment of production factors, income, and trade flows. Specifically, VA per definition includes net taxes (tax minus subsidy); thus, a typical policy shock on taxes, subsidies, or tariffs will directly affect the size of the VA flows. Simultaneously, a policy shock will impact trade flows, as depicted in the denominator of common measures. For example, tariff liberalization is expected to increase trade flows relative to GDP and increase GVC integration, whereas the tariff cuts will impact GVC integration negatively.

This study examines the effects of trade policy on GVC integration measures. That is, we explore how changes in the above-mentioned GVC indicator can be interpreted. We evaluate changes in GVC integration by examining a Free Trade Agreement (FTA) in APEC, a region that is distinguished by relatively strong GVC linkages and partly considerable tariffs. We use the global computable general equilibrium (CGE) model METRO (OECD, 2015), which differentiates trade flows by use categories and thus offers a unique possibility to decompose various linkage effects. The analysis is based on the METRO database that is extended to an inter-country input -output (ICIO) table, from where the targeted indicators can be derived.

Trade liberalization among APEC countries increases GVC integration (participation) by about $2 \%$ in most regions. However, the effects do not directly relate to membership in the trade agreement. This confirms the findings of Balié et al. (2019), who found a positive relationship 
between trade agreements and forward participation on the regional and global levels. Our results show that backward participation dominates in regions where tariffs are relatively high because a drop in tariffs increases foreign content use. Simultaneously, the considerable tariff reductions, which constitute a part of VA, reduce domestic VA exported and thus constrain forward linkages partly considerably. Forward linkages dominate in APEC regions characterized by relatively small tariff protection vis-à-vis APEC in the first place and now benefit from better access to export markets. By contrast, for non-APEC regions, increasing forward participation originates from stronger trading activities among APEC regions, thus lengthening the chain while maintaining or even decreasing gross exports.

The analysis reveals the limitations of the presented VA measures in a dynamic context. First, VA incorporates income related to policy measures. Thus, decreasing integration can reflect a lower tax burden and a more efficient, cost-reducing network. Second, the indicators represent relative relationships and do not allow an indication about the size and quality of other metrics.

Setting up the ICIO and decomposing VA and its interpretation in METRO is straightforward within the more general limitations of data quality in a global input-output framework. However, the VA decomposition of flows after a simulated policy shock reflects the structure and assumptions employed in the model and therefore requires careful interpretation. Thus, we conduct a thorough sensitivity analysis to gauge the effects of the model structure on the outcomes. The results are stable with regard to assumptions employed in the model.

A comprehensive literature explores determinants of linkages and GVC participation (see, e.g., de Backer et al., 2018 for an overview). To our knowledge, this is the first attempt to decompose the processes underlying changes in commonly used GVC integration measures. There are a handful of analysis using ex-ante models. The so-called supply chain models identify industry-to-industry trade flows (Walmsley \& Minor, 2017; Antimiani et al., 2018) and have been used to analyze the effects of the US-China Trade conflict on the Euro Area (Fusacchia, I., 2020) or the reversal of NAFTA (Walmsley \& Minor, 2017). Athukorala et al. (2018) incorporated the aspects of the fragmented production process differentiating various states of production, economies of scale, and decision-making with global rather than national perspectives in a prototype model. METRO has been used to assess the future of GVCs considering various future scenarios based on various non-VA indicators (de Backer \& Flaig, 2017) and to explore changes in GVC participation resulting from changes in agricultural policies - both trade and domestic support policies (Greenville et al., 2019a).

Noteworthily, we are not able and do not attempt to make any statement concerning how changes in the policy environment may influence the nature of the trading relationships within GVCs. Such a statement would require a model that depicts multinationals/a "global" decision-maker, fragmentation of production processes, and economies of scale within each process (Athukorala 
et al., 2018). However, the model used in this paper allows to decompose the various adjustment paths and thus evaluate changes in GVC indicators as is the focus of this study.

The remainder of this paper is structured as follows. Section 2 provides an overview of the most commonly used GVC indicators and the depiction of GVCs in CGE modeling. Section 3 describes the construction of the database and the GVC structure in APEC. Section 4 presents the model and simulation setup. Section 5 presents the results and sensitivity analysis. Finally, Section 6 concludes.

\section{Measuring GVC Integration}

GVC indicators have been derived to explore how a sector (or firm) interacts in a broader supply chain. In this way, the indicators seek upstream from a reference sector (or firm) and then downstream. From any given country's perspective there is therefore a backward looking part that shows the extent to which imports from other countries are used in the production of a country's exports; and a forward looking part that shows the extent to which a country's exports form part of a production process in another country, contributing to that other country's exports.

To characterize the forward and backward participation of a country in GVCs, different approaches have been used. At the heart of these approaches is the redefinition of trade flows from the observed gross trade to so called VA trade, that identifies the origin of value creation. The most commonly applied approach is to calculate an indicator of "vertical specialization," which was first described by Hummels et al. (2001) and refined by Koopman et al. (2010, 2014), who based the concept on one system. This indicator of vertical specialization defines value chain participation in terms of the origin of the VA embodied in exports from a reference country in terms of the backward- and forward-looking components based on VA shares of gross exports.

- Broadly, the backward participation indicator is measured as the share of foreign VA included in a country's total export value (striped arrows in Figure 1).

- The forward GVC participation indicator is measured as the share of a country's VA from its own exports included in other countries' exports (black arrows in Figure 1).

- The participation indicator represents the sum of backward and forward linkages

These indicators measure very different forms of engagement. For example, a country predominantly assembling products into final goods and subsequently exporting these will have a strong backward participation indicator but a small forward participation measure. Conversely, a country that predominantly supplies intermediates to an assembler will have a strong forward participation indicator but a small backward participation measure. 
Figure 1. Backward and forward participation: Supply and demand of intermediates

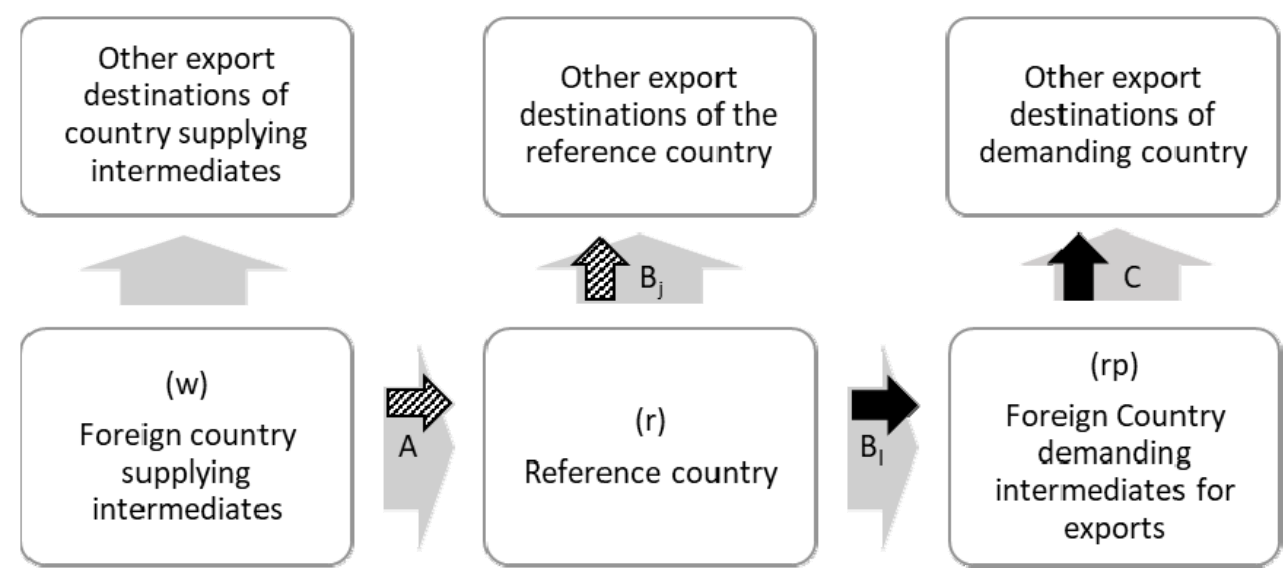

Note: Simplified representation. The striped arrows $\left(\mathrm{A}\right.$ and $\left.\mathrm{B}_{\mathrm{j}}\right)$ denote the backward linkage: the foreign value added embodied in imported intermediates used for exports of reference Country ( $\mathrm{r}$ ). The black arrows $\left(\mathrm{B}_{1}\right.$ and $\left.\mathrm{C}\right)$ denote the value added of the reference Country $(\mathrm{r})$ embodied in its exports of intermediates that are used for exports of country (rp), the forward linkage.

(Source) Adapted from Kowalski et al. (2015, p.15).

Beyond being a descriptive measure of engagement in global production networks, the indicators have been used to measure the spillover benefits on firms and industries from GVC participation. Studies that have explored various sectors - from manufacturing to services to agriculture have found that sectors with higher shares of foreign VA in exports experience faster growth rates (Kowalski et al., 2015; Lopez-Gonzalez, 2016; Greenville et al., 2019b); they also have higher export job growth rates as evidenced by Lopez-Gonzalez (2016). In essence, studies have found an associated embodied technological change from participating in global trade networks that flow from using foreign inputs, especially for developing countries (Tajoli \& Felice, 2018; Benkovskis et al., 2020).

However, for forward participation, there is less evidence allowing interpretation of the indicator. For agriculture and food sectors, forward participation described the nature of engagement, but its link to changes in domestic industries was not found (Greenville et al., $2019 b$ ). Instead, the share of domestic VA in foreign final demand was important, suggesting that the general ongoing participation in global production networks is important rather than the specific nature of that participation.

Indicators are calculated using harmonized systems of ICIOs (as in Timmer et al., 2012; OECD, 2013; De Backer \& Miroudot, 2013; UNCTAD, 2013). However, these indicators have limitations. They represent average results for industries with often very heterogeneous firm structures, in which some firms solely serve the domestic markets and others specialize in exports. In addition, there are issues related to double counting (see, e.g., Borin \& Mancini, 2019) and data availability. 
As these indicators of integration express complex relationships between trade flows and value creation, the question arises as to the interpretation of changes. For example, consider a trade agreement between two countries. The effect on GVC integration depends on the source of intermediate inputs, the membership of countries/firms up- and downstream the supply chain, and the border protection in the initial situation. As long as intermediate imports (A in Figure 1) increase stronger than gross exports (B), GVC integration increases. GVC integration also increases, when gross exports of the partner country increase $(\mathrm{C})$, all other trade flows staying constant. An increase in own gross exports (B) is ambiguous, it potentially increases forward linkages, but unless the increase in exports is not matched with a proportional increase in imported intermediates, backward integration decreases.

A major concern poses the definition of VA, which, by definition, includes net taxes and, thus, tariffs. Then, a tariff cut by the reference country will lower the country's VA exported, thereby decreasing forward participation. A tariff cut by partner countries upstream the value chain decreases imported VA and is represented by decreasing integration.

Therefore, this study aims to disentangle the various conflicting adjustment processes and evaluate the relevance of the tariff effect on the GVC indicators under consideration.

\section{Database}

The GVC module described in this paper follows the growing GVC literature (e.g., Koopman et al., 2010, 2014; Johnson \& Noguera, 2012; OECD, 2013) in deriving a set of GVC indicators and decomposing gross exports into their VA elements. A so-called ICIO table serves as basis from which various VA indicators are derived.

\section{A. Inter-country input-output table (ICIO)}

The input-output tables describe the relation between production and the use of goods and services within an economy. Meanwhile, the so-called ICIOs add an extra layer of bilateral relationships. The intermediate input matrix is at the center of the ICIO, in which the diagonal blocks represent domestic transaction flows of intermediate goods and services across industries, whereas the off-diagonal blocks represent the inter-country flows of intermediates via exports and imports.

The ICIO constructed for this study is based on the METRO database (OECD, 2015) derived from the set of harmonized input-output tables provided by the GTAP database v9 (Aguiar et al., 2016) for 2011. The database allocates imports in two steps to end-use categories and further to the specific sector. First, trade flows are distinguished by use category into intermediates, 
household, government, and capital consumption. Trade flows by use category are identified using a product-based classification of end-use (BEC) (UN, 2002) that classifies goods to end uses based on their characteristics on detailed HS6 level. Use shares for agricultural, mining, and manufacturing sectors are obtained by combining comtrade data and the BEC classification. For service sectors, data are drawn from the OECD ICIO system (Ahmad et al., 2017).

Although widely used, the BEC classification approach also has some important caveats: in some cases, goods become intermediates in use, not in characteristics. For example, tires are final goods when bought as replacement tires, but they are intermediate goods when installed in cars. Further, and deriving from the first point, there are 'miscellaneous' categories that cannot be attributed to intermediates or final demand categories; these can be important for some sectors (e.g., motor vehicles). To limit distortions, the METRO database assumes proportionality to distribute those miscellaneous categories across end-uses.

Second, the ICIO necessitates the precise identification of the links between exports of one country and the purchasing industries or final demand consumers in the importing country. This has limitations due to data availability (Ahmad et al., 2017). We follow the major ICIO projects 1 ) assuming proportionality for the allocation of trade flows over sectors inside a predefined bilateral trade flow of intermediates.

Figure 2 depicts the structure of the ICIO in METRO for two regions. Its construction broadly follows the approach outlined by Greenville et al. (2017) that has been adapted to the METRO model. When more regions are employed, $\mathrm{r} 2$ is split into row and column dimension. METRO data are available in the form of a series of regional input-output tables that distinguish imported and domestic commodity use by use category. Therefore, most entries for constructing the ICIO can directly be derived from the METRO database (or model output). The ICIO is depicted in basic prices, which has some implications in selecting prices and treatment of taxes and subsidies.2) Sectors use these measures in the same bilateral proportions even though they vary in the amount of imports used.3) The assumption is applied to all entries marked with ** in Figure 2.

1) For example, the OECD-ICIO (Ahmad et al., 2017), WIOD (Dietzenbacher et al., 2013), or ICIOs based on the GTAP database (e.g., Peters et al., 2011, Tsigas et al., 2012, Greenville et al., 2017)

2) Refer to Flaig et al. (2018) for a detailed description of prices and quantities used to construct the ICIO.

3) Aggregate (sum over source regions) import shares are sourced from GTAP and vary by activity for countries where this information is available. Although data improved strongly in recent years on this more aggregate level, data availability is still an issue, and thus, proportionality is typically applied for many countries (e.g., Ahmad et al., 2017). 
Figure 2. Structure of the inter-country input-output table in METRO

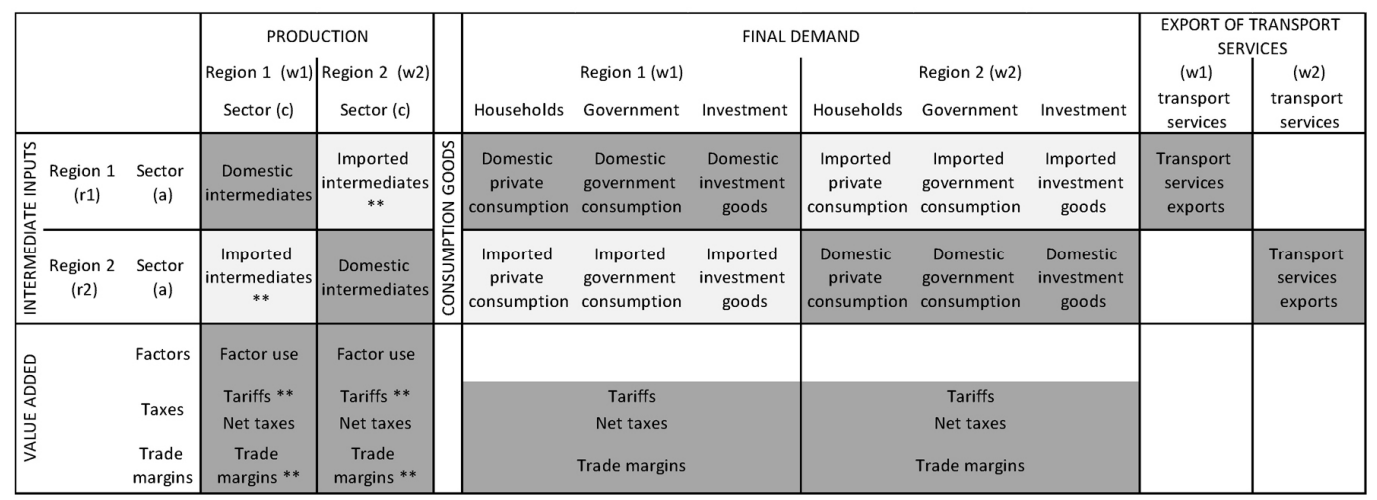

Note: For entries marked with ${ }^{* *}$, sectors use imports in the same bilateral proportions while varying in the amount of imports used.

(Source) Adapted from Flaig et al. (2018).

The production column depicts intermediate input use by sector, both domestic and imported by region. Domestic use of intermediate inputs is directly obtained from the model output.

The imported intermediate import matrix $M_{r, a, w, c}$ for imports of commodity (a) and from partner region (r) used in sector (c) in region (w) is defined as

$$
\begin{aligned}
& M_{r, a, w, c}=\text { Imports_pbasic } c_{a, u i n t, r, w} * \frac{Q M A_{a, u i n t, c, w}{ }^{*} P M A_{a, u i n t, c, w}}{\sum_{a}\left(Q M A_{a, u i n t, c, w}{ }^{*} P M A_{a, u i n t, c, w}\right)} \\
& I C I O_{r, a, w, c}=M_{r, a, w, c} \forall r \neq w+D_{r, a, w, c} \forall r=w
\end{aligned}
$$

where imported commodities are specified in basic prices (Imports_pbasic $\mathrm{c}_{\mathrm{a}, \mathrm{u}, \mathrm{r}, \mathrm{w}}$ ) and are detailed by (importing) region (w), commodity (a), (exporting) partner (r), and use category (intermediate imports uint, $\left.)^{4}\right)$ Imported intermediate input use is defined by quantity $\left(\mathrm{QMA}_{\mathrm{a}, \mathrm{uint}, \mathrm{c}, \mathrm{w}}\right)$ and price $\left(\mathrm{PMA}_{\mathrm{a}, \mathrm{uint}, \mathrm{c}, \mathrm{w}}\right)$ of imported commodity (a), used in sector (c) and region (w). The intermediate input matrix is complete with domestic intermediate inputs $\left(D_{r, a, w, c}\right.$, where $\left.\mathrm{r}=\mathrm{w}\right)$ that are directly derived from METRO variables.

Domestic and imported final demand use categories are directly derived from METRO variables. Each region exports transport services, which in METRO are specified as exports to an artificial region that acts as a neutral distributor.

The VA part of the ICIO includes factor demand, tariffs, net taxes, and trade margins. Specifically, net taxes constitute an aggregate of various policy measures depicted in the METRO

4) The ICIO is specified in basic prices; therefore, trade flows need to be expressed net of all taxes and tariffs. In order to net out export taxes, the partner's (w2) export prices $\left(\mathrm{PER}_{\mathrm{a}, \mathrm{u}, \mathrm{r} 1, \mathrm{w} 2}\right)$ for exports of commodity (a) and use category $(\mathrm{u})$ to country $(\mathrm{r} 1)$ are used to calculate the import value at basic prices (Imports_pbasic a,u,r2,w1), where $\mathrm{r} 1=\mathrm{w} 1$ and $\mathrm{r} 2=\mathrm{w} 2$. 
database, which details export taxes and various direct and indirect taxes on production, factors, goods, and household income 5 . Factor demand, net taxes, and final demand are also directly derived from METRO variables. Tariffs and trade margins on intermediates are allocated over producing activities assuming proportionality. Trade within aggregate regions is classified as domestic flows due to the structure of the ICIO.

\section{B. Value added decomposition}

VA is decomposed following the approach of Koopman et al. (2014). Let $A$ be the matrix of technological coefficients where each entry represents the necessary amount of intermediate inputs to produce one unit of output:

$$
a_{r, a, w, c}=I C I O_{r, a, w, c} / \sum_{r, a} I C I O_{r, a, w, c}
$$

where $r$ is the exporting region, $a$ denotes commodity, $w$ is the (importing) region, and $c$ is the producing sector.

In addition, let variable $V$ be defined as a diagonal matrix where each diagonal element shows the share of VA in total output, containing factor use (labor, $\mathrm{V}^{\text {lab }}$, capital, land and natural resources, $\left.\mathrm{V}^{\text {caplnd }}\right)$, tariffs $\left(\mathrm{V}^{\mathrm{tm}}\right)$, net taxes $\left(\mathrm{V}^{\mathrm{tax}}\right)$, and trade and transport margins $\left(\mathrm{V}^{\mathrm{marg}}\right)$.

$$
\begin{aligned}
& v_{w, c}=1-\sum_{r, a} a_{r, a, w, c} \\
& v_{w, c}=v_{w, c}^{l a b}+v_{w, c}^{c a p l n d}+v_{w, c}^{t m}+v_{w, c}^{t a x}+v_{w, c}^{\operatorname{marg}}
\end{aligned}
$$

Output $X$ is composed of intermediate $(A X)$ and final demand $(Y), X=A X+Y$. As $X-A X=Y$, and thus $(I-A) X=Y$, the following relationship can be derived: $X=(I-A)^{-1} Y$, where $I$ is an identity matrix.

In the input-output framework, the row and column sums are equal. Output, $X=A X+$ $V X$, equals total demand, $X=A X+Y$; therefore, $V X=Y$. The following relationships can be derived, $(\mathrm{I}-\mathrm{A}) \mathrm{X}=\mathrm{VX}$ and $\mathrm{X}=\mathrm{VX}[\mathrm{I}-\mathrm{A}]^{-1}$ or

$$
\mathrm{i}^{6}=\mathbf{V} \mathbf{i}^{\prime}[\mathbf{I}-\mathbf{A}]^{-1}
$$

with i' denoting any NK unit vector. By construction, the column sums of $V[I-A]^{-1}$ equal 1 , which is why the column sums in the value added export (VAE) matrix equal total (gross)

5) Following the ICIO literature, export taxes are special as they increase the cost of imports and thus constitute a cost for the firm that uses the good in its production process. Consequently, VA includes the value of export taxes on intermediates that are imported. 
exports. With this definition, $V[I-A]^{-1}$ captures all upstream sectors' contributions to VA in a specific sector, ultimately tracing inputs back to VA factors used in production.

Using the relationship developed above, gross exports can be decomposed into VA by source (Koopman et al., 2014). For example, let $E$ be an $N K \times N K$ diagonal matrix where each diagonal element shows the column sector's export. Then, a matrix $V[I-A]^{-1} E$ identifies the source of VA for the column sector's export. In GAMS code:

$$
V A E_{w, c, r, a}=v_{w, c} *\left[I_{w, c, r, a}-a_{w, c, r, a}\right]^{-1 *} e_{r, a}
$$

where $\mathrm{w}$ is the VA source region of intermediate good $\mathrm{c}$ used in the production of region r's export good a, and $e_{r, a}$ is a vector of gross exports, by region (r) and commodity (a).

The column dimensions of VAE capture the input composition of exports, i.e., domestic $V A$ and foreign (imported) VA that add up to gross exports in the column sum. The row dimensions show the VA use: its contribution to the sector's own exports, to total exports of a region and the use of VA in the exports of partner regions.

Several indicators can be derived (Koopman et al., 2010, 2014):

- Domestic VA in exports: represents the amount of domestic VA in exports and is identified in the VAE as exports of sector a where source region $\mathrm{w}$ and exporting region $\mathrm{r}$ are identical (summing over input commodity c).

domestic $V A_{r, a}=\sum_{c, w=r} V A E_{w, c, r, a}$

- backward participation indicator: The backward linkages represent the foreign VA share embodied in imported intermediates in exports of country r. It is calculated by dividing foreign VA by gross exports of sector a.

$i_{-}$backward $_{r, a}=\sum_{c, w \neq r} V A E_{w, c, r, a} / e_{r, a}$

- Forward participation indicator: Forward participation represents the share of a reference country's (r) VA that is exported and used as input by other countries (rp) to produce export goods (ap). The indicator is expressed as a share of the original industry's gross exports (a).

$i_{-}$forward $_{r, a}=\sum_{a p, r p \neq r} V A E_{r, a, r p, a p} / e_{r, a}$ 
- Total participation indicator: describes the overall engagement in GVCs. It is defined as the sum of backward and forward participation indicators.

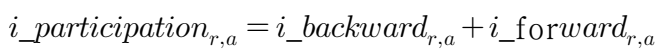

\section{GVC structure in APEC}

APEC countries are strongly integrated in GVCs. The integration strongly differs between countries (Figure 3) in size (participation) and form (backward, forward). Particularly, strong participation is observed in Korea, Malaysia, Philippines, Thailand, Vietnam and other HI-Asia. GVC participation in all these countries is dominated by strong backward linkages with foreign VA, accounting for up to $45 \%$ of the export value. Forward linkages play a relatively bigger role in Australia, Japan, Indonesia, Chile and Russia.

Figure 3. APEC is strongly integrated: backward and forward indicators by region

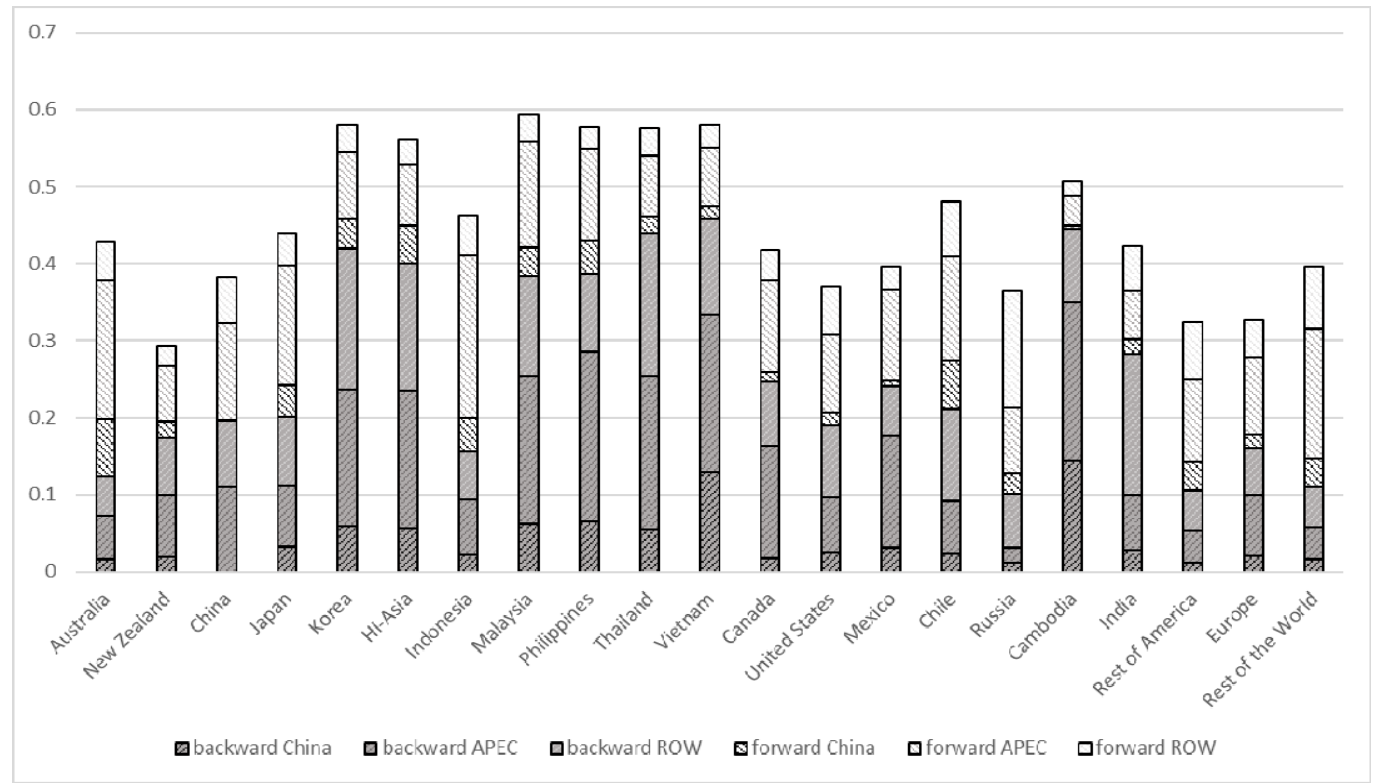

Note: Regional decomposition depicts VA flows by origin countries (backward) and destination countries (forward) of a region's exports.

APEC countries depicted in the analysis: Australia, New Zealand, China, Japan, Korea, other high-income Asian countries, Indonesia, Malaysia, Philippines, Thailand, Vietnam, Canada, United States, Mexico, Chile, and Russia. (Source) Model database

On sectoral level, the participation of single sectors varies widely (Figure Annex A1). A closer look reveals some interesting patterns, for example, Japan and China, that rank relatively low on country average, have a clearly higher sector median, relatively high minimum participation 
and relatively high participation in the third quintile of sectors identified.

Decomposing VA flows by origin countries (backward) and destination countries (forward) of a region's exports indicate a regional concentration among Asian and American countries. China is an important contributor of intermediates for exports in all countries. Being a non-APEC region, the EU is also important in backward and forward linkages in all countries, particularly for Russia. Most VA trade seems to go from high-income countries to lower-income countries and then back to high-income countries. An exception is Cambodia (non-APEC) that shows relatively strong backward and forward linkages with Vietnam and Thailand.

The non-uniform nature of tariff protection is biasing trade often in intermediates, impacting GVCs or the way value is created in GVCs. Figure 4 shows that bilateral average tariff rates (trade weighted-average) vary across the country-pairs, creating a whole system of trade diversion. For example, New Zealand, being the most efficient agricultural producer in the group, faces the highest tariffs, which is mainly due to restrictions on its ag-food exports.

Protection is concentrated on distinct products (Figure Annex A2)6). When comparing tariff rates on intra-APEC trade the highest median tariff and elevated general rates are on food products, beverages and tobacco, textiles, wearing apparel and leather, and motor vehicles.

Figure 4. Bilateral tariffs, weighted average

\begin{tabular}{|c|c|c|c|c|c|c|c|c|c|c|c|c|c|c|c|c|c|c|c|c|c|c|c|}
\hline & & \multicolumn{22}{|c|}{ importing region } \\
\hline & & 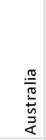 & 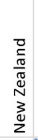 & 苞 & $\begin{array}{l}\frac{\sqrt{\pi}}{\pi} \\
\frac{0}{\pi}\end{array}$ & 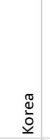 & 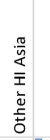 & 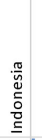 & $\begin{array}{l}\frac{\frac{\pi}{5}}{2} \\
\frac{\pi}{\frac{\pi}{10}} \\
\sum\end{array}$ & 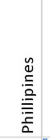 & 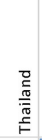 & 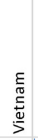 & $\begin{array}{l}\frac{\pi}{0} \\
\pi \\
\pi \\
0\end{array}$ & 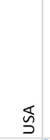 & $\begin{array}{l}\frac{\mathscr{U}}{x} \\
\frac{0}{\Sigma}\end{array}$ & $\stackrel{\frac{\Perp}{\tilde{U}}}{\mathrm{U}}$ & 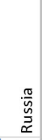 & 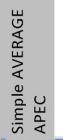 & $\begin{array}{l}\frac{\pi}{\pi} \\
0 \\
\frac{0}{\delta} \\
\tilde{J}\end{array}$ & 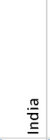 & 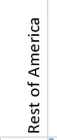 & 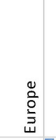 & 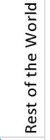 \\
\hline \multirow{22}{*}{ 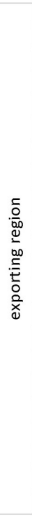 } & Australia & & $0 \%$ & $2 \%$ & $3 \%$ & $5 \%$ & $1 \%$ 【 & $4 \% \|$ & $2 \%$ & $1 \%$ & $3 \%$ & $3 \%$ & $1 \%$ & $1 \%$ & $2 \% \square$ & $6 \%$ & $9 \%$ & $3 \%$ & $11 \%$ & $5 \%$ & $3 \% \rrbracket$ & $3 \% \square$ & $6 \%$ \\
\hline & New Zealand & $0 \%$ & & $3 \%$ & $11 \%$ & $19 \%$ & $4 \%$ ] & $4 \%$ & $3 \%$ & $1 \%$ & $9 \%$ & $5 \%$ & $20 \%$ & $3 \%$ & $20 \%$ & $1 \%$ & $16 \%$ & $7 \%$ & $16 \%$ & $10 \%$ & $10 \%$ & $24 \%$ & $14 \%$ \\
\hline & China & $3 \%$ & $4 \%$ & & $3 \%$ & $6 \%$ & $1 \%$ & $1 \%$ & $4 \%$ & $1 \%$ & $8 \%$ & $7 \%$ & $4 \%$ & $3 \%$ & $6 \%$ & $2 \%$ & $10 \%$ & $4 \%$ & $11 \%$ & $7 \%$ & $13 \%$ & $4 \%$ & $10 \%$ \\
\hline & Japan & $11 \%$ & $4 \%$ & $7 \%$ & & $5 \%$ 』 & $2 \% \square$ & $8 \%$ & $9 \%$ & $2 \%$ & $9 \%$ & $5 \%$ & $3 \%$ & $1 \%$ & $3 \%$ & $0 \%$ & $14 \%$ & $5 \%$ & $12 \%$ & $8 \%$ & $12 \%$ & $3 \%$ & $9 \%$ \\
\hline & Korea & $11 \%$ & $3 \%$ & $6 \%$ & $2 \%$ & & $1 \%$ & $1 \%$ & $7 \%$ & $2 \%$ & $6 \%$ & $8 \%$ & $3 \% \mid$ & $1 \%$ & $8 \% \mid$ & $1 \%$ & $12 \%$ & $4 \%$ & $12 \%$ & $8 \%$ & $15 \%$ & $1 \%$ & $11 \%$ \\
\hline & Other HI Asia & $1 \%$ & $1 \%$ & $3 \%$ & $1 \%$ & $2 \%$ & $1 \% \rrbracket$ & $4 \%$ & $3 \%$ & $2 \%$ & $6 \%$ & $8 \%$ & $2 \%$ & $2 \%$ & $5 \%$ & $6 \%$ & $7 \%$ & $3 \%$ & $12 \%$ & $6 \%$ & ] $9 \%$ & $2 \%$ & $9 \%$ \\
\hline & Indonesia & $2 \%$ & $2 \%$ & $1 \%$ & $0 \%$ & $2 \%$ & $0 \%$ & & $2 \%$ & $0 \%$ & $8 \%$ & $4 \%$ & $4 \%$ & $5 \%$ & $12 \%$ & $6 \%$ & $11 \%$ & $4 \%$ & $7 \%$ & $35 \%$ & $11 \%$ & $3 \%$ & $8 \%$ \\
\hline & Malaysia & $0 \%$ & $1 \%$ & $2 \%$ & $0 \%$ & $2 \%$ & $0 \%$ & $0 \%$ & & $0 \%$ & $6 \%$ & $3 \%$ & $1 \% \mid$ & $1 \%$ & $5 \%$ & $6 \%$ & $8 \%$ & $2 \%$ & $11 \%$ & $20 \%$ & $9 \%$ & $1 \%$ & $9 \%$ \\
\hline & Phillipines & $0 \%$ & $1 \%$ & $0 \%$ & $1 \%$ & $4 \%$ & $0 \%$ & $0 \%$ & $3 \%$ & & $11 \%$ & $3 \%$ & $3 \%$ & $3 \%$ & $5 \%$ & $6 \%$ & $8 \%$ & $3 \%$ & $9 \%$ & $7 \%$ & $9 \%$ & $1 \%$ & $6 \%$ \\
\hline & Thailand & $0 \%$ & $1 \%$ & $2 \%$ & $5 \%$ & $8 \%$ & $1 \%$ & $2 \%$ & $2 \%$ & $1 \%$ & & $4 \%$ & $4 \% \|$ & $2 \%$ & $10 \%$ & $6 \%$ & $17 \%$ & $4 \%$ & $14 \%$ & $8 \%$ & $13 \%$ & $3 \%$ & $9 \%$ \\
\hline & Vietnam & $0 \%$ & $3 \%$ & $1 \%$ & $1 \%$ & $9 \%$ & $2 \%$ & $3 \%$ & $7 \%$ & $13 \%$ & $9 \%$ & & $7 \%$ & $7 \%$ & $19 \%$ & $6 \%$ & $10 \%$ & $6 \%$ & $12 \%$ & $13 \%$ & $21 \%$ & $4 \%$ & $8 \%$ \\
\hline & Canada & $2 \%$ & $0 \%$ & $3 \%$ & $10 \%$ & $5 \%$ & $1 \%$ & $4 \%$ & $2 \%$ & $8 \%$ & $7 \%$ & $4 \%$ & & $0 \%$ & $0 \%$ & $1 \%$ & $16 \%$ & $4 \%$ & $9 \%$ & $16 \%$ & $7 \%$ & $1 \%$ & $5 \%$ \\
\hline & USA & $1 \%$ & $2 \%$ & $5 \%$ & $6 \%$ & $28 \%$ & $1 \%$ & $4 \%$ & $3 \%$ & $4 \%$ & $5 \%$ & $5 \%$ & $1 \%$ & & $0 \%$ & $0 \%$ & $10 \%$ & $5 \%$ & $17 \%$ & $8 \%$ & $6 \%$ & $2 \%$ & $5 \%$ \\
\hline & Mexico & $5 \%$ & $2 \%$ & $5 \%$ & $7 \%$ & $4 \%$ & $1 \%$ & $4 \%$ & $5 \%$ & $3 \%$ & $8 \%$ & $5 \%$ & $0 \%$ & $0 \%$ & & $0 \%$ & $16 \%$ & $4 \%$ & $12 \%$ & $2 \%$ & $2 \%$ & $0 \%$ & $4 \%$ \\
\hline & Chile & $0 \%$ & $0 \%$ & $0 \%$ & $3 \%$ & $2 \%$ & $1 \%$ & $2 \% \rrbracket$ & $2 \%$ & $3 \% \rrbracket$ & $3 \%$ & $4 \% \mid$ & $1 \%$ & $1 \%$ & $1 \%$ & & $10 \%$ & $2 \%$ & $23 \%$ & $3 \%$ & $1 \%$ & $1 \%$ & $3 \%$ \\
\hline & Russia & $0 \%$ & $1 \%$ & $1 \%$ & $1 \%$ & $3 \%$ & $0 \%$ & $2 \%$ & $5 \%$ & $0 \%$ & $1 \%$ & $6 \%$ & $1 \%$ & $0 \%$ & $1 \%$ [ & $5 \%$ & & $2 \%$ & $7 \%$ & $8 \%$ & $2 \%$ & $0 \%$ & $3 \%$ \\
\hline & Simple AVERAGE & $2 \%$ & $2 \%$ & $3 \%$ & $3 \%$ & $6 \%$ & $1 \%$ & $3 \%$ & $4 \%$ & $3 \%$ & $6 \%$ & $5 \%$ & $3 \%$ & $2 \%$ & $6 \%$ 】 & $3 \%$ & $11 \%$ & $4 \%$ & & & & & \\
\hline & Cambodia & $0 \%$ & $0 \%$ & $2 \%$ & $0 \%$ & $6 \%$ & $1 \%$ & $0 \%$ & $6 \%$ & $0 \%$ & $14 \%$ & $4 \%$ & $0 \%$ & $13 \%$ & $28 \%$ & $6 \%$ & $18 \%$ & & & $35 \%$ & $28 \%$ & $0 \%$ & $7 \%$ \\
\hline & India & $5 \%$ & $3 \%$ & $2 \%$ & $1 \%$ & $14 \%$ & $1 \%$ & $4 \%$ & $4 \%$ & $7 \%$ & $9 \%$ & $8 \%$ & $4 \%$ & $2 \%$ & $11 \%$ & $6 \%$ & $9 \%$ & 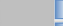 & $8 \%$ & & $7 \%$ & $2 \%$ & $7 \%$ \\
\hline & Rest of America & $1 \%$ & $2 \%$ & $3 \%$ & $2 \%$ & $23 \%$ & $0 \%$ & $5 \%$ & $4 \%$ & $4 \%$ & $8 \%$ & $3 \%$ & $2 \%$ & $1 \%$ & $5 \%$ & $0 \%$ & $19 \%$ & & $9 \%$ & $5 \%$ & $0 \%[$ & $5 \%$ & $6 \%$ \\
\hline & Europe & $5 \%$ & $3 \%$ & $8 \%$ & $4 \%$ & $7 \%$ & $1 \%$ & $6 \%$ & $6 \%$ & $4 \%$ & $6 \%$ & $5 \%$ & $3 \% \mid$ & $1 \%$ & $0 \%$ & $0 \%$ & $10 \%$ & & $8 \%$ & $10 \%$ & $10 \%$ & & $5 \%$ \\
\hline & Rest of the World & $1 \%$ & $0 \%$ & $1 \%$ & $0 \%[$ & $4 \%$ & $0 \%$ & $2 \%[$ & $4 \%$ & $1 \% \mid$ & $1 \%$ & $4 \%$ & $1 \%$ & $1 \%$ & $5 \% \rrbracket$ & $3 \%$ & $4 \%$ & & $8 \% \rrbracket$ & $2 \%$ & $2 \%$ & $1 \%$ ] & $4 \%$ \\
\hline
\end{tabular}

(Source) model database

6) Regional detail for agro-food and manufacturing is presented in Annex Figure A3. 


\section{Model and Simulation Setup}

\section{A. METRO model}

METRO is a static multi-country CGE model (OECD, 2015) derived from the Social Accounting Matrix (SAM) based CGE model GLOBE (McDonald \& Thierfelder, 2013) using GAMS software7).

In the model production is depicted through a three-level nested production process. In the first nest, intermediate demand and factor demand form output using Constant Elasticity of Substitution (CES) technology. In the second nest, aggregate intermediate demand is formed by intermediates in fixed proportions using Leontief technology. Factor demand is formed by two composites, a composite of skilled labor categories and capital and a composite of unskilled labor categories, together with land and natural resources.

All goods and related equations in the model are distinguished by use category into commodities designed for intermediate use, use for consumption by households and government, and investment commodities. Each sector and the agents (household, government and investment) source goods from domestic supply and imports. Imports are modeled as three-stage nested CES function assuming imperfect substitutability between domestically produced and imported goods 8 ). Export commodities are treated as imperfect substitutes using a two-level Constant Elasticity of Transformation (CET) formulation that allows for price differentiation on the domestic and export markets depending on market shares and price elasticities.

\section{B. Simulation setup}

This study analyzes effects of trade policy on instruments used to measure GVC integration. For this purpose, we run a simple APEC free trade scenario. The APEC region is distinguished by relative strong GVC linkages and partly considerable tariffs. These tariffs are set to zero in the scenario.

The VA decomposition and GVC indicators derive from the VAE Matrix described above. The VAE is composed of VA use, intermediate input use, and gross exports as depicted in equation (7) and further specified in equation (13):

$$
\begin{aligned}
V A E_{w, c, r, a} & =v_{w, c} *\left[I_{w, c, r, a}-a_{w, c, r, a}\right]^{-1 *} e_{r, a} \\
& =\left(v_{w, c}^{l a b}+v_{w, c}^{c a p l n d}+v_{w, c}^{t m}+v_{w, c}^{t a x}+v_{w, c}^{\operatorname{marg}}\right) *\left[I_{w, c, r, a}-a_{w, c, r, a}\right]^{-1 *} e_{r, a}
\end{aligned}
$$

7) The model is a direct descendant of an early US Department of Agriculture model (Robinson et al., 1990) and follows trade principles from the 1-2-3 model (de Melo \& Robinson, 1989; Devarajan et al., 1990). Refer to OECD (2015) for a detailed documentation of the model.

8) The model includes a feature that allows a special treatment for small shares (typically defined as less than $0.01 \%$ of imports in a sector) and import these in fixed proportions. 
where $\mathrm{w}$ is the VA source region of the intermediate good $\mathrm{c}$ used in the production of region r's export good $\mathrm{a} ; v_{w, c}$ is the VA used to produce good $\mathrm{c}$ in region $\mathrm{w}$ and its components labor $v_{w, c}^{l a b}$, capital and land $v_{w, c}^{\text {caplnd }}$, tariffs $v_{w, c}^{t m}$, other taxes $v_{w, c}^{t a x}$ and margins $v_{w, c}^{\operatorname{marg}} ; a_{w, c, r, a}$ the matrix of intermediate input coefficients and $e_{r, a}$ is a vector of gross exports, by region (r) and commodity (a).

All the elements defining the VAE are affected in a simulation, i.e., for the tariff scenario as applied in this paper:

- The policy simulation lowers tariffs and thus directly affects VA generated from taxes, $v_{w, c^{*}}^{t m}$.

- VA generated from the production factors, $v_{w, c}^{l a b}+v_{w, c}^{c a p l n d}$, are affected due to general equilibrium effects, where the relationship to each other and the other variables are determined by production structure and mobility setup.

- VA accruing from trade and transport margins, $v_{w, c}^{\text {marg }}$, in METRO is related to the quantity imported.

- The intermediate input coefficients, $a_{w, c, r, a}$, do not change in METRO due to the Leontief assumption in in the respective production nesting.

- Gross exports, $e_{r, a}$, are featured in the VAE calculation and are also in the denominator of the indicators.

The METRO database is aggregated to 21 regions detailing APEC countries, 8 factors of production and 47 sectors (Table 1). Trade, production and income elasticities are sourced from the GTAP database.

The model is specified as follows: (1) all production factors are fully employed and mobile; (2) government expenditure is adjusting to changing tax income while all tax rates are fixed; (3) a flexible exchange rate balances the current account; and (4) investment follows GDP in fixed shares.

Given the limitations related to the modelling of GVCs, a thorough sensitivity analysis is conducted to gauge the effects of various model specifics, such as closures, elasticities or production structure, on the outcomes. 
Table 1. Aggregation: Regions, Factors, and Sectors

\begin{tabular}{|c|c|c|c|c|c|}
\hline \multicolumn{6}{|l|}{ Regions } \\
\hline \multicolumn{6}{|l|}{$A P E C$} \\
\hline Australia & New Zealand & China & Japan & Korea & Other HI Asia \\
\hline Indonesia & Malaysia & Philippines & Thailand & Vietnam & Canada \\
\hline United States & Mexico & Chile & Russia & & \\
\hline \multicolumn{6}{|l|}{ Other regions } \\
\hline Cambodia & India & Rest of America & Europe & Rest of the World & \\
\hline \multicolumn{6}{|l|}{ FACTORS } \\
\hline $\begin{array}{l}\text { Technical and assistant } \\
\text { professionals }\end{array}$ & Clerks & $\begin{array}{l}\text { Service and shop } \\
\text { assistants }\end{array}$ & $\begin{array}{l}\text { Office managers } \\
\text { and professionals }\end{array}$ & $\begin{array}{l}\text { Agricultural and } \\
\text { other low skilled } \\
\text { workers }\end{array}$ & \\
\hline Land & Capital & Natural resources & & & \\
\hline \multicolumn{6}{|l|}{ SECTORS } \\
\hline Paddy rice & Cereal grains & $\begin{array}{l}\text { Vegetables fruit } \\
\text { other crops }\end{array}$ & Oil seeds & $\begin{array}{l}\text { Sugar cane sugar } \\
\text { beet }\end{array}$ & $\begin{array}{l}\text { Plant-based } \\
\text { fibers }\end{array}$ \\
\hline Cattle & Other animals & Milk & $\begin{array}{l}\text { Wool silk-worm } \\
\text { cocoons }\end{array}$ & $\begin{array}{l}\text { Forestry and } \\
\text { Fishing }\end{array}$ & $\begin{array}{l}\text { Natural } \\
\text { Resources }\end{array}$ \\
\hline $\begin{array}{l}\text { Meat: cattle sheep } \\
\text { goats horse }\end{array}$ & $\begin{array}{l}\text { Meat products } \\
\text { nec }\end{array}$ & $\begin{array}{l}\text { Vegetable oils } \\
\text { and fats }\end{array}$ & Dairy products & Processed rice & Sugar \\
\hline Food products nec & $\begin{array}{l}\text { Beverages and } \\
\text { tobacco products }\end{array}$ & Textiles & Wearing apparel & Leather products & Wood products \\
\hline $\begin{array}{l}\text { Paper products } \\
\text { publishing }\end{array}$ & $\begin{array}{l}\text { Petroleum, coal } \\
\text { products }\end{array}$ & $\begin{array}{l}\text { Chemical rubber } \\
\text { plastic prods }\end{array}$ & $\begin{array}{l}\text { Mineral products } \\
\text { nec }\end{array}$ & Ferrous metals & Metals nec \\
\hline Metal products & $\begin{array}{l}\text { Motor vehicles } \\
\text { and parts }\end{array}$ & $\begin{array}{l}\text { Transport } \\
\text { equipment nec }\end{array}$ & $\begin{array}{l}\text { Electronic } \\
\text { equipment }\end{array}$ & $\begin{array}{l}\text { Machinery and } \\
\text { equipment nec }\end{array}$ & Manufacture nec \\
\hline Utilities & Construction & Trade & $\begin{array}{l}\text { Transport } \\
\text { services }\end{array}$ & Communication & $\begin{array}{l}\text { Financial } \\
\text { services nec }\end{array}$ \\
\hline Insurance & $\begin{array}{l}\text { Business services } \\
\text { nec }\end{array}$ & $\begin{array}{l}\text { Recreation and } \\
\text { other services }\end{array}$ & $\begin{array}{l}\text { Public Admin. } \\
\text { Defense Health } \\
\text { Education }\end{array}$ & Dwellings & \\
\hline
\end{tabular}

\section{Simulation Results}

\section{A. Gross effects and domestic VA}

As expected, trade liberalization among APEC countries increases trade, as shown in Table 2. The effect is stronger for Asian countries as they are starting from higher regional integration, relative to the Americas and Russia, and relatively high trade barriers. Trade diversion effects exist for non-APEC regions. GDP and production effects are small and positive in most countries, and increase most noticeable in Korea, Malaysia and Vietnam. Reduced government income from tariff liberalization dampens GDP effects and subsequently production increases are larger 
than GDP effects for all APEC regions. The effect is particularly strong for regions where tariff income contributes an important share to GDP, such as Vietnam (5\%), Thailand (3\%), Korea (3\%) and Malaysia (2\%).

Table 2. APEC Trade Liberalization: Effects on Real GDP, Real Production, Gross Trade Flows, and Domestic VA Exported (Changes in \% to Base Data)

\begin{tabular}{|c|c|c|c|c|c|}
\hline & $G D P$ & Production & Gross Imports $^{a}$ & Gross Exports $^{a}$ & $\begin{array}{c}\text { Domestic } V A \\
\text { exported }^{a}\end{array}$ \\
\hline Australia & $0,1 \%$ & $0,4 \%$ & $3,6 \%$ & $3,6 \%$ & $3,3 \%$ \\
\hline New Zealand & $0,0 \%$ & $0,7 \%$ & $5,0 \%$ & $5,0 \%$ & $5,2 \%$ \\
\hline China & $-0,2 \%$ & $-0,1 \%$ & $5,7 \%$ & $4,7 \%$ & $3,9 \%$ \\
\hline Japan & $0,3 \%$ & $0,7 \%$ & $6,5 \%$ & $6,9 \%$ & $6,7 \%$ \\
\hline Korea & $1,8 \%$ & $3,5 \%$ & $8,2 \%$ & $8,4 \%$ & $6,6 \%$ \\
\hline Other HI Asia & $0,1 \%$ & $0,7 \%$ & $3,3 \%$ & $2,6 \%$ & $2,1 \%$ \\
\hline Indonesia & $0,1 \%$ & $0,4 \%$ & $4,7 \%$ & $4,4 \%$ & $3,4 \%$ \\
\hline Malaysia & $1,0 \%$ & $1,6 \%$ & $5,0 \%$ & $4,5 \%$ & $2,8 \%$ \\
\hline Philippines & $0,0 \%$ & $0,2 \%$ & $2,5 \%$ & $3,2 \%$ & $3,3 \%$ \\
\hline Thailand & $0,0 \%$ & $1,7 \%$ & $6,4 \%$ & $6,4 \%$ & $3,7 \%$ \\
\hline Vietnam & $0,9 \%$ & $5,2 \%$ & $13,6 \%$ & $17,5 \%$ & $9,0 \%$ \\
\hline Canada & $0,3 \%$ & $0,3 \%$ & $2,6 \%$ & $2,6 \%$ & $2,6 \%$ \\
\hline$U S A$ & $0,0 \%$ & $0,1 \%$ & $2,0 \%$ & $3,4 \%$ & $3,4 \%$ \\
\hline Mexico & $0,1 \%$ & $0,2 \%$ & $1,9 \%$ & $1,8 \%$ & $1,4 \%$ \\
\hline Chile & $0,0 \%$ & $0,4 \%$ & $1,4 \%$ & $1,1 \%$ & $1,2 \%$ \\
\hline Russia & $0,2 \%$ & $0,1 \%$ & $2,9 \%$ & $2,1 \%$ & $1,9 \%$ \\
\hline Cambodia & $-0,3 \%$ & $-0,8 \%$ & $-2,2 \%$ & $-2,4 \%$ & $-2,1 \%$ \\
\hline India & $0,0 \%$ & $-0,1 \%$ & $0,0 \%$ & $-0,2 \%$ & $-0,2 \%$ \\
\hline Rest of America & $0,0 \%$ & $0,0 \%$ & $-0,1 \%$ & $-0,1 \%$ & $-0,1 \%$ \\
\hline Europe & $0,0 \%$ & $-0,1 \%$ & $-0,6 \%$ & $-1,0 \%$ & $-0,9 \%$ \\
\hline Rest of the World & $0,0 \%$ & $-0,1 \%$ & $0,2 \%$ & $0,1 \%$ & $0,2 \%$ \\
\hline
\end{tabular}

${ }^{\text {a }}$ nominal, at basic prices

(Source) model results

China experiences negative GDP and production effects. In China, a decreasing trade balance (imports increase stronger than exports) meets a relatively high decrease in government income from tariffs. This effect on government income is larger in absolute terms than for other countries with decreasing trade balance9).

Domestic VA that is incorporated in a region's exports increases for APEC regions (Table 2). In about half of the APEC regions and all non-APEC regions domestic VA exported changes

9) Consequential GDP effects are positive for China when varying the closure setup and balancing the government balance with a flexible income tax or letting the government balance adjust (Annex 2). 
similar to gross exports. In the other half of the APEC regions' domestic VA increases less than gross exports, i.e., Vietnam, Thailand, Malaysia, and Korea. Figure 5 shows that these are the countries with sizable tariff reductions. Tariffs are entering VA in the form of net taxes and a reduction of tariffs thus constitutes an actual reduction of VA attributed to the production of a specific product. When only considering VA originating from production factors and other elements, excluding the tariff reduction, VA increases stronger than gross exports for all APEC countries, except Vietnam.

Figure 5 also demonstrates how similar changes in domestic VA exported can represent differing effects. For example, Japan and Korea experience a similar increase in domestic VA exported by $6.6 \% / 6.7 \%$. However, factor VA, GDP and gross trade effects are considerably stronger for Korea.

Figure 5. Effects on domestic VA exported (\% changes to base data)

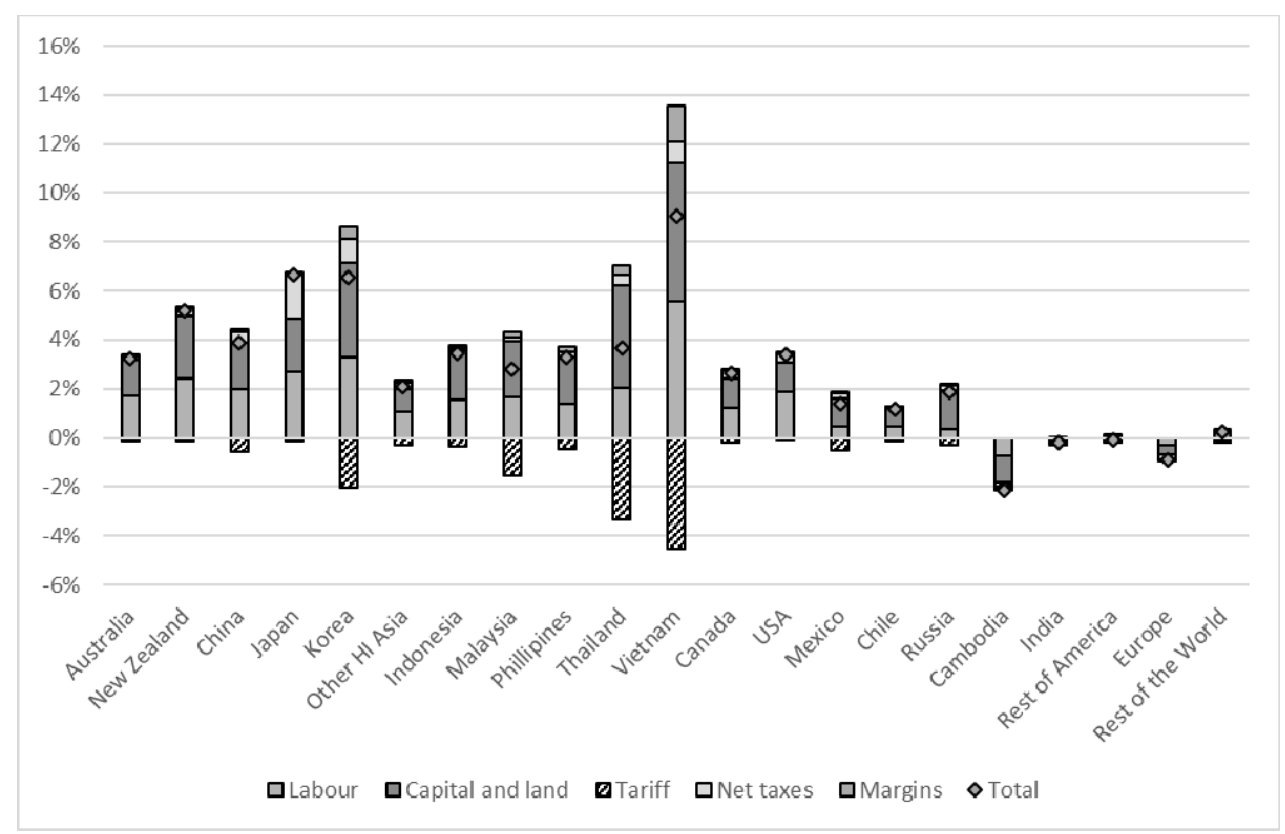

(Source) model results

\section{B. GVC integration}

Participation increases in all regions except New Zealand (Figure 6). Most notably, the size of changes in participation is with about $2 \%$ similar in the majority APEC and non-APEC regions. The regions, however, differ by type of integration. Participation in the first group is dominated by stronger forward linkages, i.e., Australia, Japan, Philippines, HI-Asia and the American regions. These regions benefit from better access to export markets and are characterized 
by relatively small tariff protection vis-à-vis APEC. In the second group backward participation dominates, i.e., China, Korea, Indonesia, Malaysia, Thailand and Vietnam. A special case is New Zealand, and partly Thailand and Vietnam, with decreasing indicator values. A final group is the non-APEC regions with increasing forward and slightly negative backward linkages.

Figure 6. Effects on participation and contribution of backward and forward linkages (\% changes to base data)

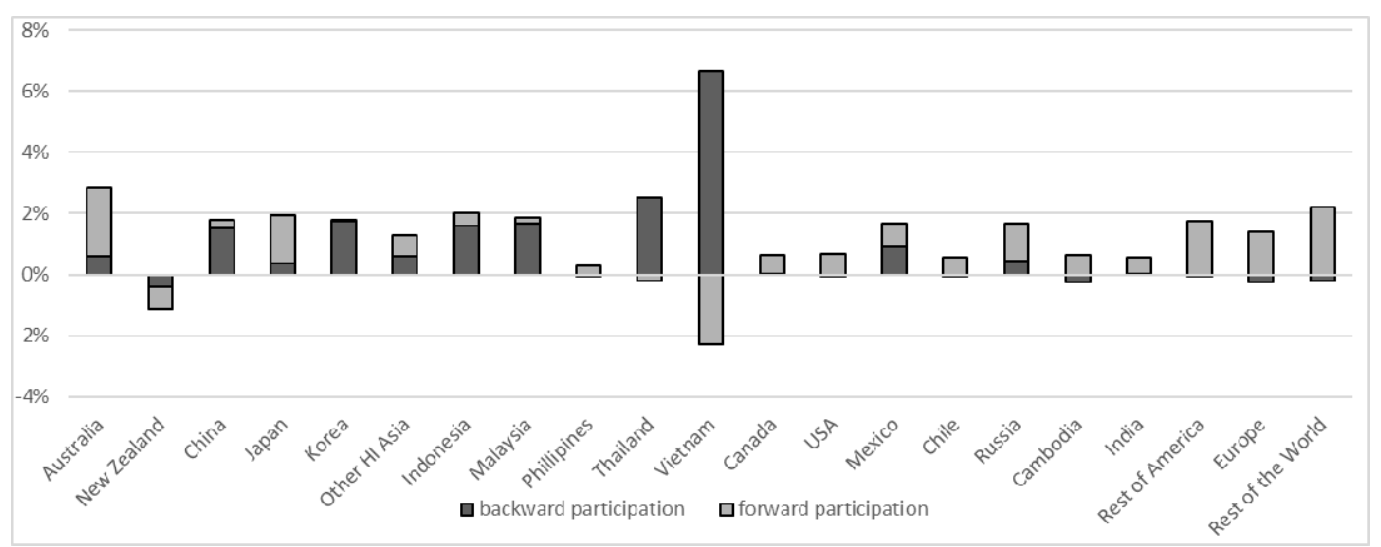

(Source) Model results

Tariffs on intermediates increased domestic content use, but at the expense of lower value generation (lower exports overall). Thus, the drop in tariffs now increases foreign content use and changes in backward participation dominate where tariffs used to be relatively high. Simultaneously, being part of VA, the tariff reductions in these regions reduce domestic VA exported (Table 3, Column 4a) and thus reduce the forward indicator. This tariff effect can be high; i.e., for China, Korea, Malaysia, and Thailand, where the change in forward participation would be more than twice as high without the tariff effect.

Decreasing backward integration, as in New Zealand, does not imply falling use of foreign VA, contrary, the use of foreign VA increases in all APEC regions (Table 3, Column 2). The backward indicator reflects the relative relationship between gross trade and foreign VA. Thus, backward integration increases when the foreign VA content in exports increases stronger than gross exports and decreases when gross exports rise relatively stronger. This is the case for New Zealand where exports were facing relatively high tariffs and now benefit from better market access, and imports see only moderate changes; in effect, New Zealand increases its domestic content share in exports.

The tariff reduction in the FTA decreases foreign tax value in exports and thus FVA (Table 3, Columns 2 and 2a). The value-reducing effect is rather moderate and comes at the sometimes very significant growth in return to factors of production. Interestingly, the tariff effect is biggest for Cambodia, which is a non-APEC member and therefore not part of the FTA. In Cambodia, 
$40 \%$ of the FVA value decrease can be attributed to lower tax burdens in other countries. When imports arrive in Cambodia (or other countries) they have overall had lesser tax paid on them and so the world saves from a more efficient GVC network in APEC.

Table 3. Decomposing Effects of Backward and Forward Integration (Hanges to Base Data)

\begin{tabular}{|c|c|c|c|c|c|c|c|}
\hline & $\begin{array}{l}\text { (1) Gross } \\
\text { exports }\end{array}$ & $\begin{array}{l}\text { (2) Foreign } \\
\text { VA in exports }\end{array}$ & $\begin{array}{c}\text { (2a) ppt } \\
\text { contribution } \\
\text { of tariff to (2) }\end{array}$ & $\begin{array}{c}\text { (3) } \\
\text { Backward } \\
\text { indicator }\end{array}$ & $\begin{array}{l}\text { (4) } V A \text { in } \\
\text { partner's } \\
\text { exports }\end{array}$ & $\begin{array}{c}\text { (4a) ppt } \\
\text { contribution of } \\
\text { tariff to (4) }\end{array}$ & $\begin{array}{l}\text { (5) } \\
\text { Forward } \\
\text { indicator }\end{array}$ \\
\hline Australia & $3,6 \%$ & $5,7 \%$ & $-0,3 \%$ & $2,0 \%$ & $6,8 \%$ & $-0,1 \%$ & $3,2 \%$ \\
\hline New Zealand & $5,0 \%$ & $4,3 \%$ & $-0,2 \%$ & $-0,7 \%$ & $3,1 \%$ & $-0,1 \%$ & $-1,8 \%$ \\
\hline China & $4,7 \%$ & $7,8 \%$ & $-0,3 \%$ & $3,0 \%$ & $5,2 \%$ & $-0,6 \%$ & $0,5 \%$ \\
\hline Japan & $6,9 \%$ & $7,7 \%$ & $-0,3 \%$ & $0,8 \%$ & $10,0 \%$ & $-0,1 \%$ & $2,9 \%$ \\
\hline Korea & $8,4 \%$ & $11,1 \%$ & $-0,2 \%$ & $2,4 \%$ & $8,7 \%$ & $-1,9 \%$ & $0,2 \%$ \\
\hline Other HI Asia & $2,6 \%$ & $3,5 \%$ & $-0,3 \%$ & $0,8 \%$ & $5,2 \%$ & $-0,3 \%$ & $2,4 \%$ \\
\hline Indonesia & $4,4 \%$ & $9,3 \%$ & $-0,5 \%$ & $4,8 \%$ & $5,0 \%$ & $-0,3 \%$ & $0,6 \%$ \\
\hline Malaysia & $4,5 \%$ & $7,1 \%$ & $-0,4 \%$ & $2,6 \%$ & $5,1 \%$ & $-1,6 \%$ & $0,6 \%$ \\
\hline Philippines & $3,2 \%$ & $3,2 \%$ & $-0,4 \%$ & $0,0 \%$ & $4,1 \%$ & $-0,6 \%$ & $0,8 \%$ \\
\hline Thailand & $6,4 \%$ & $9,9 \%$ & $-0,3 \%$ & $3,3 \%$ & $5,4 \%$ & $-3,3 \%$ & $-0,9 \%$ \\
\hline Vietnam & $17,5 \%$ & $27,4 \%$ & $-0,5 \%$ & $8,5 \%$ & $4,8 \%$ & $-3,7 \%$ & $-10,7 \%$ \\
\hline Canada & $2,6 \%$ & $2,6 \%$ & $-0,2 \%$ & $0,0 \%$ & $4,2 \%$ & $-0,1 \%$ & $1,6 \%$ \\
\hline$U S A$ & $3,4 \%$ & $3,4 \%$ & $-0,2 \%$ & $0,0 \%$ & $4,8 \%$ & $-0,1 \%$ & $1,4 \%$ \\
\hline Mexico & $1,8 \%$ & $3,3 \%$ & $-0,3 \%$ & $1,5 \%$ & $3,8 \%$ & $-0,5 \%$ & $2,0 \%$ \\
\hline Chile & $1,1 \%$ & $1,0 \%$ & $-0,2 \%$ & $-0,1 \%$ & $2,2 \%$ & $-0,1 \%$ & $1,0 \%$ \\
\hline Russia & $2,1 \%$ & $3,7 \%$ & $-0,2 \%$ & $1,6 \%$ & $3,8 \%$ & $-0,3 \%$ & $1,7 \%$ \\
\hline Cambodia & $-2,4 \%$ & $-2,7 \%$ & $-1,0 \%$ & $-0,3 \%$ & $2,5 \%$ & $0,1 \%$ & $5,0 \%$ \\
\hline India & $-0,2 \%$ & $-0,2 \%$ & $-0,2 \%$ & $0,0 \%$ & $1,4 \%$ & $0,0 \%$ & $1,6 \%$ \\
\hline Rest of America & $-0,1 \%$ & $-0,3 \%$ & $-0,2 \%$ & $-0,2 \%$ & $2,5 \%$ & $0,0 \%$ & $2,6 \%$ \\
\hline Europe & $-1,0 \%$ & $-1,5 \%$ & $-0,3 \%$ & $-0,5 \%$ & $1,7 \%$ & $0,0 \%$ & $2,8 \%$ \\
\hline Rest of the World & $0,1 \%$ & $-0,6 \%$ & $-0,3 \%$ & $-0,8 \%$ & $3,2 \%$ & $0,0 \%$ & $3,0 \%$ \\
\hline
\end{tabular}

Note: The FTA is decreasing tariffs which impact on the respective VA measures (2) and (4) by the percentage points indicated in (2a) and (4a), respectively.

(Source) model results

Forward participation depends on own VA incorporated in the partner's exports and the own exports. It increases when the relative relationship between these two metrics changes (Table 3). Thus, an increasing forward indicator can be triggered by increased use of VA in partner's exports, e.g., Australia and Japan, or be related to decreasing exports, e.g., Cambodia. In this study, decreasing forward linkages in Vietnam, Thailand and New Zealand do instead reflect increasing reexport of VA and even stronger increasing exports.

Non-APEC regions experience increased GVC participation in the form of stronger forward linkages. While effects on exports are small the effect originates from stronger trading activities 
among APEC regions. The slightly negative effects on backward participation originate from trade diversion decreasing FVA in non-APEC exports.

Noteworthily, the change of indicators reflects relative relationships and does not allow an interpreting the size of effects. For example, gross exports and FVA increase stronger in Korea $(8.4 \%, 11.1 \%)$ compared to China $(4.7 \%, 7.8 \%)$. However, in China, the relative increase of FVA is bigger and thus the backward indicator increases stronger (3\% China, 2.4\% Korea). Or with respect to the forward indicator, the increase in exports and VA in partner's exports in Mexico $(1.8 \%, 3.8 \%)$ is considerably smaller compared to Korea $(8.4 \%, 8.7 \%)$, but forward integration increases stronger in Mexico (2.0\% Mexico, $0.2 \%$ Korea).

Indicators also do not allow to make a note on the performance of typically relevant metrics. For example, the backward integration for Cambodia and Canada did not show any changes. However, clear differences exist between the countries that should validate a diverging assessment; thus, exports and FVA decrease in Cambodia and increase in Canada. For both countries both metrics change about the same amount and thus do not change the backward indicator.

\section{Sensitivity analysis}

The simulation results are influenced by various assumptions incorporated in the model structure. Important for the GVC indicators are foremost assumptions affecting, first, the relationship between VA and intermediates, i.e., the specification of production; second, the size of exports, i.e., heterogeneous exports and trade elasticities; and third, assumptions affecting the relative relationship of VA elements, i.e., capital.

Figure 7 illustrates effects on GDP and participation for various model setups and maps these against the effects from the "standard setup" as analyzed in the section above10).

\section{Production}

The first set of simulations analyses the variations in the production setup. The production tree in the model version used in the main body of this study, henceforth referred to as the "standard model," form output combining intermediate demand and VA using CES technology. Switching the assumption to Leontief technology on the first level ("First-Level Leontief") eliminates one possible adjustment path and therefore results in smaller effects for GDP, participation, and (slightly) also domestic VA exported (Figure 7a).

VA in the standard model is formed by a two-level nesting, where a composite of skilled labor categories and capital, a composite of unskilled labor categories, together with land and natural resources form VA. A simplification of this nesting by bringing all elements on one level ("VA on 1 level") has minor impacts on the results, effects on GDP are without clear

10) Detailed results are presented in Annex 2. 
trend, effects on participation and domestic VA exported are slightly smaller.

The standard model forms aggregate intermediate demand in fixed proportions using Leontief technology. Switching the assumption from Leontief to CES ("intermediates CES"), and thus allowing for changing technology coefficients, renders slightly more positive effects for GDP with Korea constituting one positive outlier, the trend is clearer for participation and domestic VA exported (Annex 2). The apparent negative entries in Figure 7a represent the effects for Cambodia.

Figure 7. Changes in GDP, participation and domestic value added by model setup

\section{a) Production Structure}
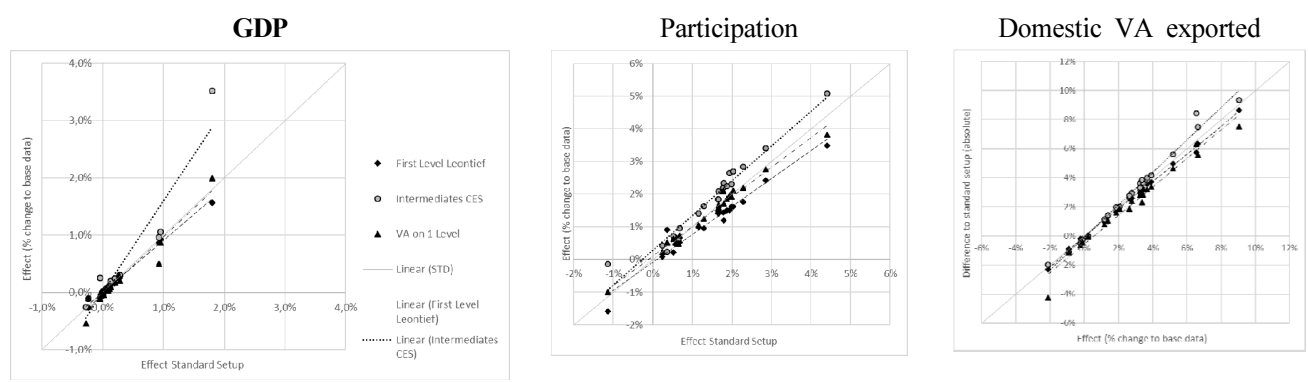

b) Trade
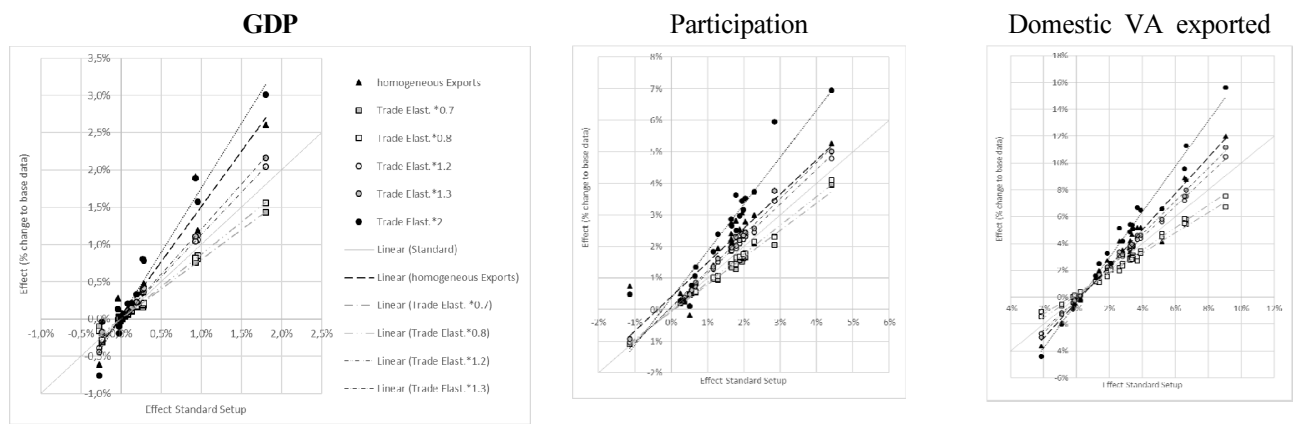

c) Closure
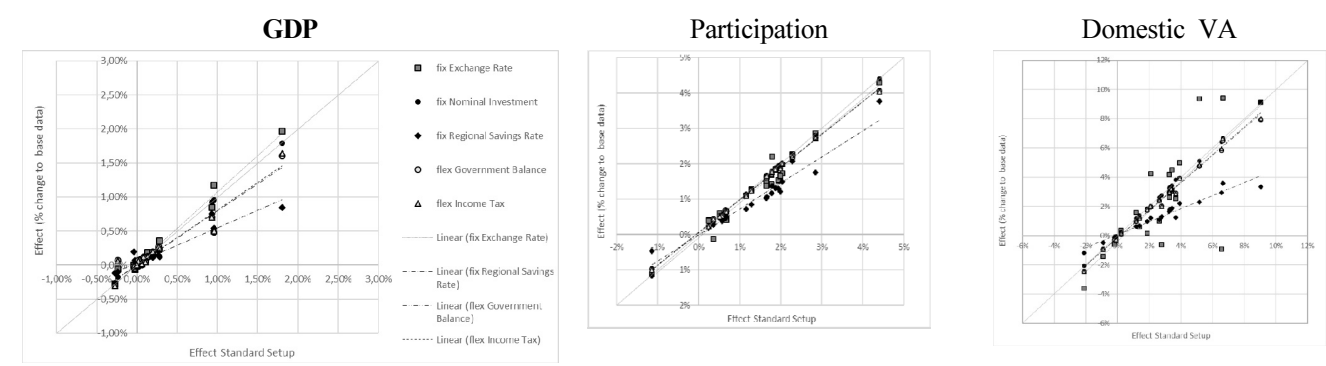

\section{Trade}

The model employs trade elasticities sourced from the GTAP database and assumes imperfect substitutability on the import and export side. Both, imports and exports, are modeled as 
two-level-nested CES/CET structure with domestic supply and traded quantities at lower level. On the upper level, traded quantities are sourced/distributed bilaterally. Export elasticities are mirroring the import side on both levels. The trade structure is tested by varying trade elasticities and changing the trade structure to homogeneous exports. We rerun the simulation with variations of trade elasticities, $-30 \%,-20 \%,+20 \%,+30 \%$ and double 11$)$. As expected, higher trade elasticities increase and smaller elasticities decrease effects in both positive and negative directions (Figure 7b). In size, trade elasticities strongly influence the level of effects but do not affect relative relationships.

Abandoning the assumption of heterogeneity of exports and implementing homogeneous exports allows the model to better allocate products to export or domestic markets as required, decreasing necessary price changes. Homogenous exports lead to higher effects on participation and GDP. Most notably, higher trade elasticities and homogeneous exports lead to positive participation effects for New Zealand (Annex 2).

\section{Closures}

A variation of closure conditions reveals that the closure specification on investment and savings strongly affects the level of results. In the standard model investment follows GDP in fixed shares, fixing nominal investment ("fix nominal investment") instead has no relevant effect. Assuming savings driven investment, where the savings rate is defined a fixed share of regional income ("fix regional savings rate"), leads to considerably smaller effects compared to the standard model, results are smaller and less negative. The fixed savings rate increases domestic savings and lowers foreign savings leading to efficiency losses and thus smaller effects.

The government specification ("flex government balance" and "flex income tax") impacts the level of outcome for GDP; effects with respect to participation and domestic VA exported are minor. Effects on GDP are higher with "fix exchange rate", minor for participation and without clear trend for domestic VA exported.

\section{Conclusions}

This study analyzes the effects of trade policy on GVC integration measures and decompose changes in GVC integration. As expected, trade liberalization among APEC countries increases trade and domestic VA incorporated in exports. The effect is stronger for Asian countries as they are starting from relatively high trade barriers and higher regional integration relative to

11) Changing the propensity to trade within APEC only does not lead to significantly different outcomes compared to changing all of it for all regions. 
American countries and Russia. Abstracting from tariffs, which downsize domestic VA, the remainder of domestic VA exported increases more than gross exports for all APEC countries. Especially, the effects for Vietnam, Thailand, Korea, and Malaysia are distinct.

Participation effects do not relate directly to membership in the trade agreement and increases in the majority of regions, APEC and non-APEC, by about $2 \%$. The regions, however, differ by type of integration. The group where forward linkages dominate, i.e., Australia, Japan, Philippines, HI-Asia and the American regions, benefit from better access to export markets and are characterized by relatively small tariff protection vis-à-vis APEC. Backward participation dominates in countries where tariffs used to be relatively high as the drop in tariffs increases foreign content use, i.e., China, Korea, Indonesia, Malaysia, Thailand and Vietnam. Simultaneously, being part of VA, the tariff reductions in these regions reduce domestic VA exported and thus, in parts severely, constrain forward linkages.

Decreasing backward integration, as observed for New Zealand, does not imply falling use of foreign VA which in fact increases for all APEC regions. Backward integration increases when the foreign VA content in exports increases stronger than gross exports. A region where exports were facing relatively high tariffs and with relatively low tariffs on imports, for example, New Zealand, will benefit from better market access, and experience only moderate changes on the import side, thus its domestic content share in exports increases and in consequence the backward indicator decreases.

For non-APEC regions, the change in participation is dominated by stronger forward linkages. Exports by non-APEC regions, however, stay constant and the change originates from stronger trading activities among APEC regions strengthening the forward linkages. Trade diversion leads to slightly negative effects on backward participation.

The tariff reduction in the FTA decreases foreign tax value in exports and thus foreign VA. Consequently, the lower tax burdens and more efficient GVC networks impact VA measures negatively. Interestingly, the tariff effect is biggest for Cambodia, which is not part of the FTA, where $40 \%$ of the foreign VA decrease can be attributed to lower tax burdens in other countries.

The analysis reveals the limitations of the presented VA measures in a dynamic context. Aggregated indicators cannot give insights about performance on metrics that are typically in the focus of analysis, but can be insightful as long as these indicators are used as starting point for deeper analysis. Care is needed when interpreting indicators: First, VA incorporates income related to policy measures and thus decreasing integration can reflect a lower tax burden and a more efficient network with cost reduction. Second the indicators represent relative relationships and do not allow an indication about size and quality of other metrics. Our results are relatively stable with regard to assumptions employed in the model.

Removing taxes from the trade value we see a relatively large replacement by returns to VA factors. However, interpreting the change in indicators itself cannot be taken at face value. 
This study is unable and does not attempt to make any statement concerning changes in the nature of the trading relationships within GVCs following a policy event. This type of analysis would require a model that depicts multinationals, fragmentation of production processes, and economies of scale within each process as, e.g., presented as a prototype in Athukorala et al. (2018). The integration of these features in a global or regional model with multiple sectors will pose a major task concerning data requirements and computation.

\section{References}

Aguiar, A., Narayanan, B., \& McDougall, R. (2016). An overview of the GTAP 9 data base. Journal of Global Economic Analysis, 1(1), 181-208.

Ahmad, N., Bohn, T., Mulder, N., Vaillant, D. \& Zaclicever, D. (2017). Indicators on global value chains: A guide for empirical work. OECD Statistics Working Papers, 2017(08), OECD Publishing, Paris. http://doi.org/10.1787/8502992f-en

Antimiani, A., Salvatici, L., \& Fusacchia, I. (2018). GTAP-VA: An integrated tool for global value chain analysis. Journal of Global Economic Analysis, 3(2), 69-105.

Athukorala, P.-C., Dixon, P. B., \& Rimmer, M. T. (2018). Global supply chains: Towards a computable general equilibrium analysis. Economic Papers, 37(3), 198-219.

Baldwin, R. (2012). Trade and industrialisation after globalisation's second unbundling: How building and joining a supply chain are different and why it matters. In R. Feenstra, \& A. Taylor (Eds.), Globalization in an Age of Crisis: Multilateral Economic Cooperation in the Twenty-First Century. University of Chicago Press.

Baldwin, R. (2016). The Great Convergence, Information Technology and the New Globalisation. Harvard University Press.

Balié, J., Del Prete, D., Magrini, E., Montalbano, P., \& Nenci, S. (2019). Does trade policy impact food and agriculture global value chain participation of sub-Saharan African countries? American Journal of Agricultural Economics, 101(3), 773-789.

Benkovskis, K., Masso, J., Tkacevs, O., Vahter, P., \& Yashiro, N. (2020). Export and productivity in global value chains: Comparative evidence from Latvia and Estonia. Review of World Economics, 156(3), 557-577.

Borin, A., \& Mancini, M. (2019). Measuring what matters in global value chains and value-added trade. World Bank Policy Research Working Paper No. 8804.

Bureau, J., Guimbard, H., \& Jean, S. (2019). Competing liberalizations: Tariffs and trade in the twenty-First Century. Review of World Economics, 155(4), 707-753.

De Backer, K., De Lombaerde, P., \& Iapadre, L. (2018). Analyzing global and regional value chains. International Economics, 153, 3-10.

De Backer, K., \& Flaig, D. (2017). The future of global value chains: Business as usual or "a new normal”? OECD Science, Technology and Industry Policy Papers, No. 41, OECD Publishing, Paris. 
https://doi.org/10.1787/d8da8760-en

De Backer, K., \& Miroudot, S. (2013). Mapping global value chains. OECD trade policy Papers, No. 159, OECD Publishing, Paris. https://doi.org/10.1787/5k3vltrgnbr4-en

de Melo, J., \& Robinson, S. (1989). Product differentiation and the treatment of foreign trade in computable general equilibrium models of small economies. Journal of International Economics, 27(1/2), 47-67.

Devarajan, S., Lewis, J. D., \& Robinson, S. (1990). Policy lessons from trade-focused, two-sector models. Journal of Policy Modeling, 12(4), 625-657.

Dietzenbacher, E., Los, B., Stehrer, R., Timmer, M., \& de Vries, G. (2013). The construction of world input-output tables in the WIOD project. Economic Systems Research, 25(1), 71-98.

Flaig, D., Kawasaki, K., \& Greenville, J. (2018). METRO Development: The ICIO-TIVA-Module, a method to analyse global value chains with metro. OECD Metro Model Development Series TAD/TC/CA/WP/RD, 1, OECD, Paris.

Fusacchia, I. (2020). Evaluating the impact of the US-China trade war on Euro Area economies: A tale of global value chains. Italian Economic Journal, 6(3), 441-468.

Greenville, J., Kawasaki, K., \& Beaujeu, R. (2017). A method for estimating global trade in value added within agriculture and food value chains. OECD Food, Agriculture and Fisheries Papers, No. 99, OECD Publishing, Paris. http://doi.org/10.1787/f3a84910-en

Greenville, J., Kawasaki, K., Flaig, D., \& Carrico, C. (2019a). Influencing GVCs through agro-food policy and reform. OECD Food, Agriculture and Fisheries Papers, No. 125, OECD Publishing, Paris. https://doi.org/10.1787/9ce888e0-en

Greenville, J., Kawasaki, K., \& Jouanjean, M. (2019b). Dynamic changes and effects of agro-food GVCS. OECD Food, Agriculture and Fisheries Papers, No. 119, OECD Publishing, Paris. https://doi.org/10.17 87/43b7bcec-en

Hummels, D., Ishii, J., \& Yi, K.-M. (2001). The nature and growth of vertical specialization in world trade. Journal of International Economics, 54(1), 75-96.

Johnson, R. C., \& Noguera, G. (2012). Accounting for intermediates: Production sharing and trade in value-added. Journal of International Economics, 86(2), 224-236.

Koopman, R., Wang, Z., \& Wei, S.-J. (2014). Tracing value-added and double counting in gross exports. American Economic Review, 104(2), 459-494.

Koopman, R., Powers, W., Wang, Z., \& Wei, S.-J. (2010). Give credit where credit is due: Tracing value added in global production chains. NBER Working Paper, No. 16426.

McDonald, S., \& Thierfelder, K. E. (2013). Globe v1: A SAM based global CGE model using GTAP data, model documentation. Available at: http://www.cgemod.org.uk/

Kowalski, P., Lopez Gonzalez, J., Ragoussis, A., \& Ugarte, C. (2015). Participation of developing countries in global value chains: Implications for trade and trade-related policies. OECD Trade Policy Papers, 179, OECD Publishing, Paris. https://doi.org/10.1787/5js33lfw0xxn-en

Lopez-Gonzalez, J. (2016). Using foreign factors to enhance domestic export performance: A Focus on Southeast Asia. OECD Trade Policy Papers, 191, OECD Publishing, Paris. http://doi.org/10.1787/5jlpq 82v1jxw-en

OECD. (2015). Metro v1 model documentation. TAD/TC/WP(2014)24/FINAL. 
OECD. (2013). Interconnected economies: Benefiting from global value chains, OECD publishing, Paris. http://doi.org/10.1787/9789264189560-en

Peters, G. P., Andrew, R., \& Lennox, J. (2011). Constructing an environmentally extended multi-Regional input-output table using the GTAP database. Economic Systems Research, 23(2), 131-152.

Robinson, S., Kilkenny, M., \& Hanson, K. (1990). USDA/ERS Computable general equilibrium model of the United States. Economic Research Services, USDA, Staff Report Ages 9049.

Tajoli, L., \& Felice, G. (2018). Global value chains participation and knowledge spillovers in developed and developing countries: An empirical investigation. European Journal of Development Research, 30(3), 505-532.

Timmer, M., Erumban, A. A., Gouma, R., Los, B., Temurshoev, U., de Vries, G. J., Arto, I., Genty, V. A. A., Neuwahl, F., Rueda-Cantuche, J. M., Villanueva, A., Francois, J., Pindyuk, O., Pöschl, J., Stehrer, R., \& Streicher, G. (2012). The World Input-Output Database (WIOD): Contents, sources and methods. version 0.9, April 2012, WIOD Background Document. Available at: http://www.wiod.org

Tsigas, M., Wang, Z., \& Gehlhar, M. (2012). How a global inter-country input output table with processing trade account can be constructed from GTAP database. Paper presented at the 15th annual conference for global trade analysis, July 28, Geneva.

UN. (2002). Classification by broad economic categories. Statistical Papers. Series M, 53, Rev \& United Nations. New York.

UNCTAD. (2013). Global value chains: Investment and trade for development. World Investment Report. United Nations Conference on Trade and Development.

Walmsley, T., \& Minor, P. (2017). Reversing NAFTA: A supply chain perspective. Impact. ECON working paper. presented at GTAP conference, Purdue, June, March. 


\section{Annex 1. Additional Data}

Figure A1. GVC participation indicator, sectoral distribution by country

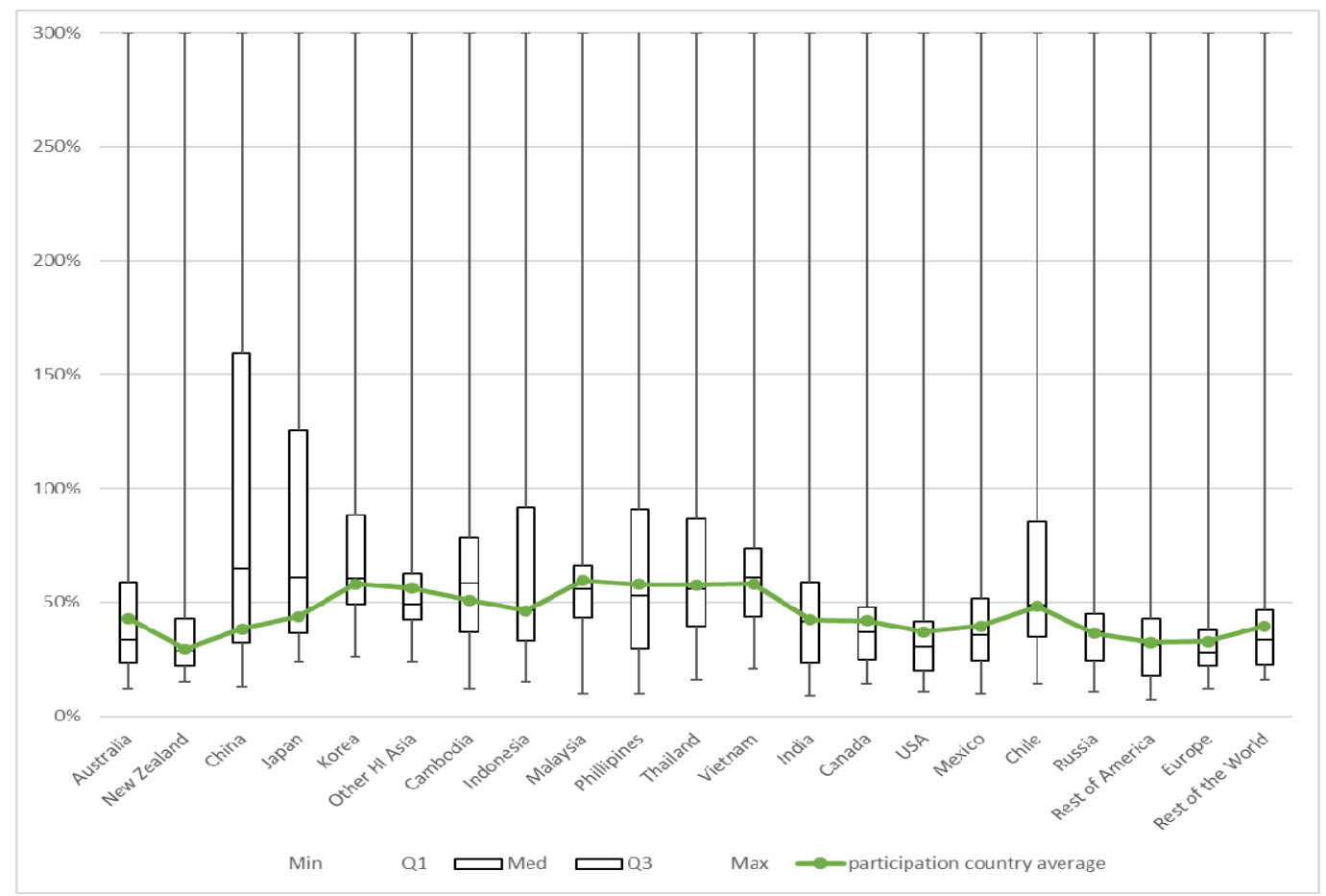

(Source) model database

Figure A2. Tariff protection by sector on intra-APEC trade, distribution

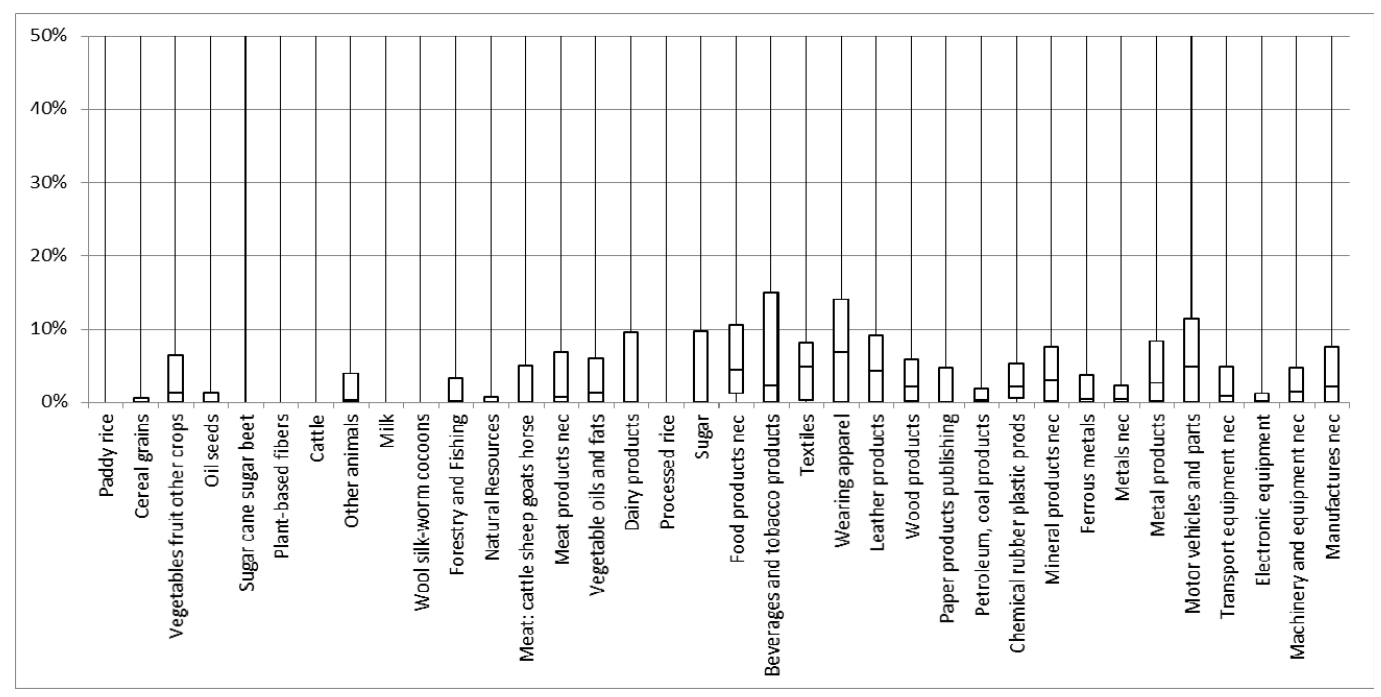

(Source) model database 
Figure A3. Bilateral tariffs, weighted-average

a) Tariffs on agriculture and food products

\begin{tabular}{|c|c|c|c|c|c|c|c|c|c|c|c|c|c|c|c|c|c|c|c|c|c|c|}
\hline & 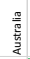 & 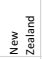 & 墨 & 㩊 & 遌 & 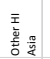 & 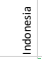 & $\begin{array}{l}\frac{\frac{m}{3}}{3} \\
\frac{\frac{\pi}{3}}{2} \\
\frac{\pi}{2}\end{array}$ & 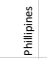 & 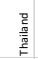 & 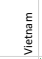 & 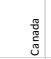 & 离 & $\frac{\frac{8}{x}}{\frac{x}{2}}$ & $\frac{\underline{\nu}}{\frac{\partial}{u}}$ & 总 & $\frac{1}{4} \frac{u}{\alpha} \frac{u}{\alpha}$ & 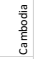 & 要 & 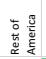 & 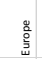 & 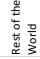 \\
\hline Australia & & $8 \%$ & $2 \%$ & $10 \%$ & $126 \%$ & $4 \%$ & $1 \%$ & $4 \%$ & $10 \%$ & $8 \%$ & $14 \%$ & $1 \%$ & $2 \%$ & $1 \%$ & $3 \%$ & $4 \%$ & $12 \%$ & $13 \%$ & $18 \%$ & $6 \%$ & $13 \%$ & $3 \%$ \\
\hline New Zealand & $2 \%$ & & $2 \%$ & $24 \%$ & $8 \%$ & $3 \%$ & $1 \%$ & $3 \%$ & $3 \%$ & $5 \%$ & $3 \%$ & $38 \%$ & $7 \%$ & $0 \%$ & $8 \%$ & $11 \%$ & $7 \%$ & $7 \%$ & $79 \%$ & $4 \%$ & $24 \%$ & $4 \%$ \\
\hline China & $1 \%$ & $7 \%$ & & $22 \%$ & $5 \%$ & $7 \%$ & $11 \%$ & $11 \%$ & $12 \%$ & $11 \%$ & $17 \%$ & $1 \%$ & $5 \%$ & $4 \%$ & $3 \%$ & $4 \%$ & $8 \%$ & $5 \%$ & $4 \%$ & $2 \%$ ] & $6 \%$ & $5 \%$ \\
\hline Japan & $2 \%$ & $11 \%$ & $18 \%$ & & $19 \%$ & $5 \%$ & $39 \%$ & $18 \%$ & $19 \%$ & $35 \%$ & $99 \%$ & $2 \%$ & $24 \%$ & $4 \%$ & $17 \%$ & $15 \%$ & $20 \%$ & $11 \%$ & $10 \%$ & $8 \%$ & $24 \%$ & $3 \%$ \\
\hline Korea & $1 \%$ & $3 \%$ & $12 \%$ & $23 \%$ & & $17 \%$ & $27 \%$ | & $1 \%$ & $9 \%$ & $37 \%$ & $76 \%$ & $10 \%$ & $15 \%$ & $7 \%$ & $15 \%$ & $17 \%$ & $17 \%$ & $5 \%$ & $8 \%$ & $10 \%$ & $35 \%$ & $11 \%$ \\
\hline Other HII Asia & $2 \%$ & $2 \%$ & $4 \%$ & $49 \%$ & $21 \%$ & $6 \%$ & $47 \%$ & $0 \%$ & $11 \%$ & $22 \%$ & $22 \%$ & $7 \%$ & $15 \%$ & $2 \%$ & $13 \%$ & $12 \%$ & $15 \%$ & $5 \%$ & $19 \%$ & $9 \%$ & $12 \%$ & $11 \%$ \\
\hline Indonesia & $3 \%$ & $7 \%$ & $2 \%$ & $6 \%$ & $42 \%$ & $8 \%$ & & $23 \%$ & $17 \%$ & $29 \%$ & $66 \%$ & $10 \%$ & $9 \%$ & $6 \%$ & $4 \%$ & $16 \%$ & $15 \%$ & $8 \%$ & $53 \%$ & $16 \%$ & $22 \%$ & $6 \%$ \\
\hline Malaysia & $2 \%$ & $6 \%$ & $11 \%$ & $33 \%$ & $6 \%$ & $14 \%$ & $51 \%$ & & $4 \%$ & $25 \%$ & $42 \%$ & $83 \%$ & $12 \%$ & $8 \%$ & $10 \%$ & $16 \%$ & $20 \%$ & $39 \%$ & $13 \%$ & $14 \%$ & $27 \%$ & $5 \%$ \\
\hline Phillipines & $0 \%$ & $0 \%$ & $3 \%$ & $362 \%$ & $11 \%$ & $5 \%$ ] & $17 \%$ & $1 \%$ & & $29 \%$ & $14 \%$ & $6 \%$ & $5 \%$ & $0 \%$ & $1 \%$ & $4 \%$ & $29 \%$ & $0 \%$ & $11 \%$ & $3 \%$ & $7 \%$ & $2 \%$ \\
\hline Thailand & $3 \%$ & $5 \%$ & $3 \%$ & $26 \%$ & $8 \%$ & $8 \%$ & $6 \%$ & $9 \%$ & $19 \%$ & & $21 \%$ & $6 \%$ & $2 \% \mid$ & $1 \%$ & $18 \%$ & $8 \%$ & $9 \%$ & $2 \%$ & $29 \%$ & $6 \%$ & $15 \%$ & $3 \%$ \\
\hline Vietnam & $1 \%$ & $3 \%$ & $59 \%$ & $10 \%$ & $12 \%$ & $11 \%$ & $0 \%$ & $1 \%$ & $25 \%$ & $17 \%$ & & $4 \%$ & $7 \%$ & $0 \%$ & $6 \%$ & $12 \%$ & $11 \%$ & $2 \%$ & $27 \%$ & $10 \%$ & $12 \%$ & $4 \%$ \\
\hline Canada & $0 \%$ & $7 \%$ & $3 \%$ & $8 \%$ & $141 \%$ & $6 \%$ & $6 \%$ & $3 \%$ & $6 \%$ & $17 \%$ & $17 \%$ & & $12 \%$ & $1 \%$ & $4 \%$ & $10 \%$ & $15 \%$ & $3 \%$ & $2 \%$ & $7 \%$ & $5 \%$ & $4 \%$ \\
\hline USA & $1 \%$ & $3 \%$ & $4 \%$ & $12 \%$ & $24 \%$ & $3 \%$ & $14 \%$ & $14 \%$ & $5 \%$ & $3 \%$ & $15 \%$ & $10 \%$ & & $1 \%$ & $8 \%$ & $3 \%$ & $7 \%$ & $3 \%$ & $16 \%$ & $7 \%$ & $14 \%$ & $5 \%$ \\
\hline Mexico & $2 \%$ & $11 \%$ & $5 \%$ & $10 \%$ & $3 \%$ & $16 \%$ & $39 \%$ & $49 \%$ & $13 \%$ & $45 \%$ & $1 \%$ & $4 \%$ & $8 \%$ & & $17 \%$ & $3 \%$ & $14 \%$ & $5 \%$ & $5 \%$ & $10 \%$ & $18 \%$ & $7 \%$ \\
\hline Chile & $1 \%$ & $9 \%$ & $15 \%$ & $164 \%$ & $34 \%$ & $17 \%$ & $22 \%$ & $12 \%$ & $6 \%$ & $81 \%$ & ${ }_{91} 1 \%$ & \% & $6 \%$ & $1 \%$ & & $13 \%$ & $30 \%$ & $8 \%$ & $17 \%$ & $7 \%$ & $8 \%$ & $4 \%$ \\
\hline Russia & $3 \%$ & $6 \%$ & $1 \%$ & $6 \%$ & $2 \%$ & $5 \%$ & $90 \%$ & $8 \%$ & $12 \%$ & $14 \%$ & $26 \%$ & $1 \%$ & $0 \%$ & $0 \%$ & $19 \%$ & & $12 \%$ & $10 \%$ & $3 \%$ & $5 \%$ & $12 \%$ & $4 \%$ \\
\hline Simple AVERAGE APEC & $2 \%$ & $6 \%$ & $9 \%$ & $48 \%$ & $29 \%$ & $8 \%$ & $23 \%$ & $10 \%$ & $11 \%$ & $24 \%$ & $33 \%$ & $12 \%$ & $8 \%$ & $2 \%$ & $9 \%$ & $9 \%$ & $15 \%$ & & & & & \\
\hline Cambodia & $1 \%$ & $6 \%$ & $8 \%$ & $15 \%$ & $4 \%$ & $6 \%$ & $4 \%$ & $3 \%$ & $11 \%$ [ & $10 \%$ & $17 \%$ & $2 \%$ & $5 \%$ & $1 \%$ & $8 \%$ & $2 \%$ & & & $5 \%$ & $7 \%$ & $14 \%$ & $4 \%$ \\
\hline India & $1 \%$ & $4 \%$ & $2 \%$ & $6 \%$ & $121 \%$ & $7 \%$ & $5 \%$ & $35 \%$ & $11 \%$ & $22 \%$ & $23 \%$ & $10 \%$ & $4 \%$ & $0 \%$ & $9 \%$ & $12 \%$ & & $6 \%$ & & $8 \%$ & $15 \%$ & $6 \%$ \\
\hline Rest of America & $0 \%$ & $2 \%$ & $1 \%$ & $6 \%$ & $39 \%$ & $8 \%$ & $3 \%$ & $4 \%$ & $3 \%$ & $16 \%$ & $5 \%$ & $3 \%$ & $3 \%$ & $2 \%$ & $14 \%$ & $6 \%$ & & $8 \%$ & $2 \%$ & $6 \%$ & $7 \%$ & $3 \%$ \\
\hline Europe & $1 \%$ & $8 \%$ & $5 \%$ & $6 \%$ & $11 \%$ & $11 \%$ & $22 \%$ & $1 \%$ & $5 \%$ & $30 \%$ & $79 \%$ & $4 \%$ & $10 \%$ & $3 \%$ & $11 \%$ & $5 \%$ & & $16 \%$ & $4 \%$ & $6 \%$ & $6 \%$ & $3 \%$ \\
\hline Rest of the World & $2 \%$ & $3 \%$ & $3 \%$ & $12 \%$ & $9 \%$ & $2 \%$ & $2 \%$ & $2 \%$ & $2 \%$ ] & $21 \%$ & $19 \%$ & $1 \%$ & $9 \%$ & $4 \%$ & $2 \%$ & $5 \%$ & & $16 \%$ & $2 \%$ & $9 \%$ & $6 \%$ & $3 \%$ \\
\hline
\end{tabular}

b) Tariffs on manufacturing

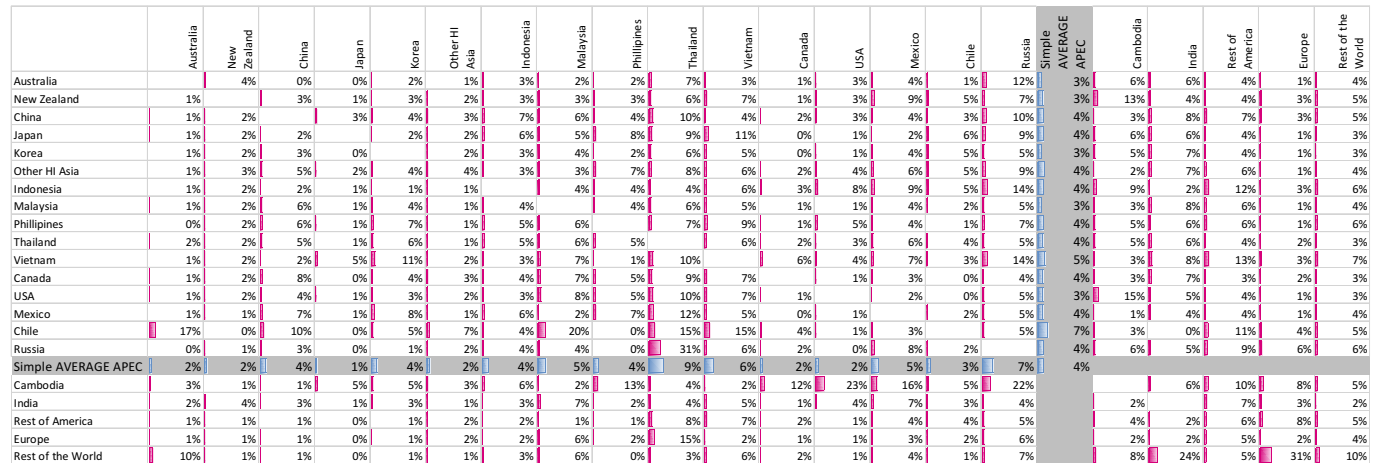

(Source) Model database 


\section{Annex 2. Additional Results}

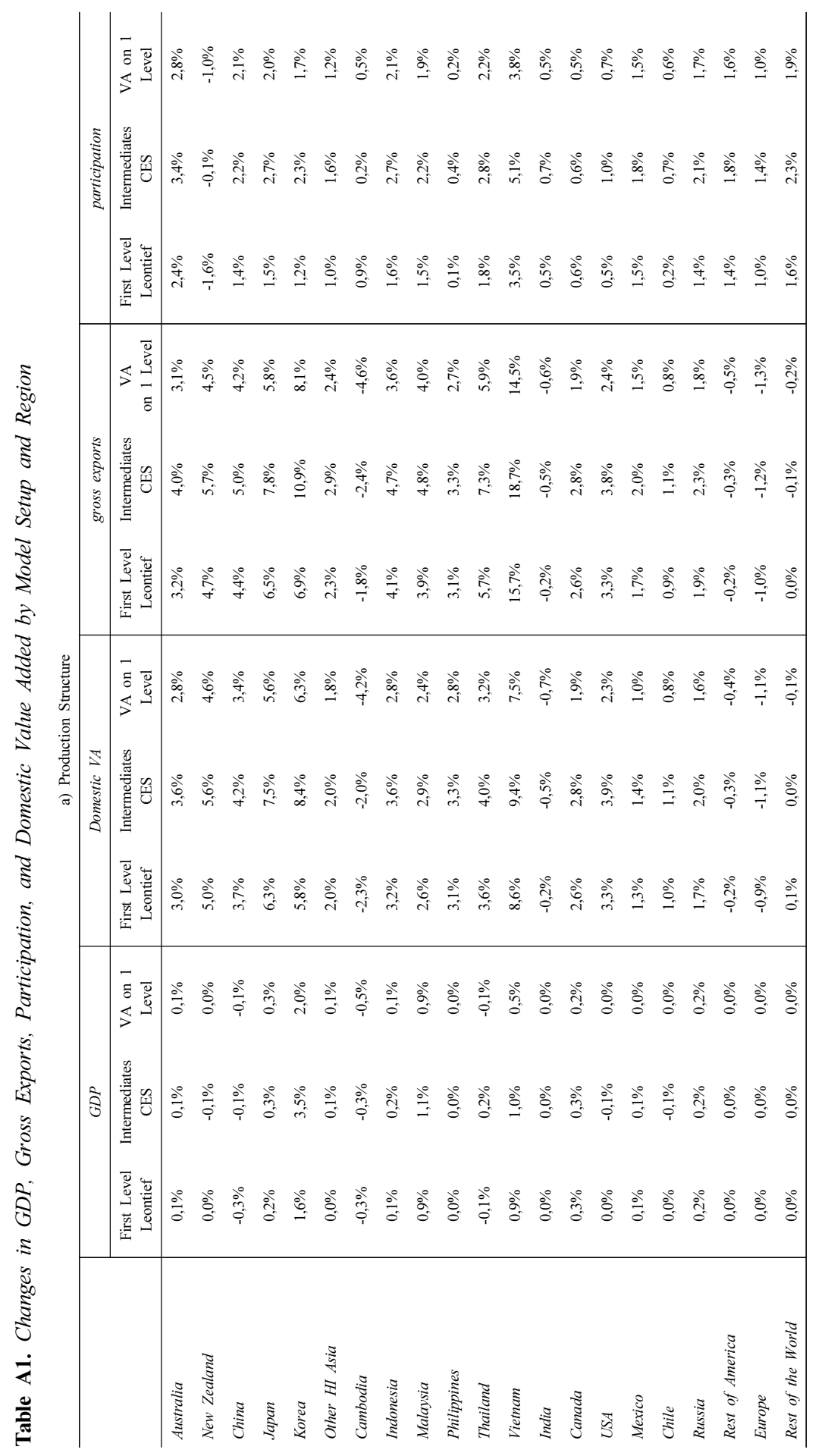




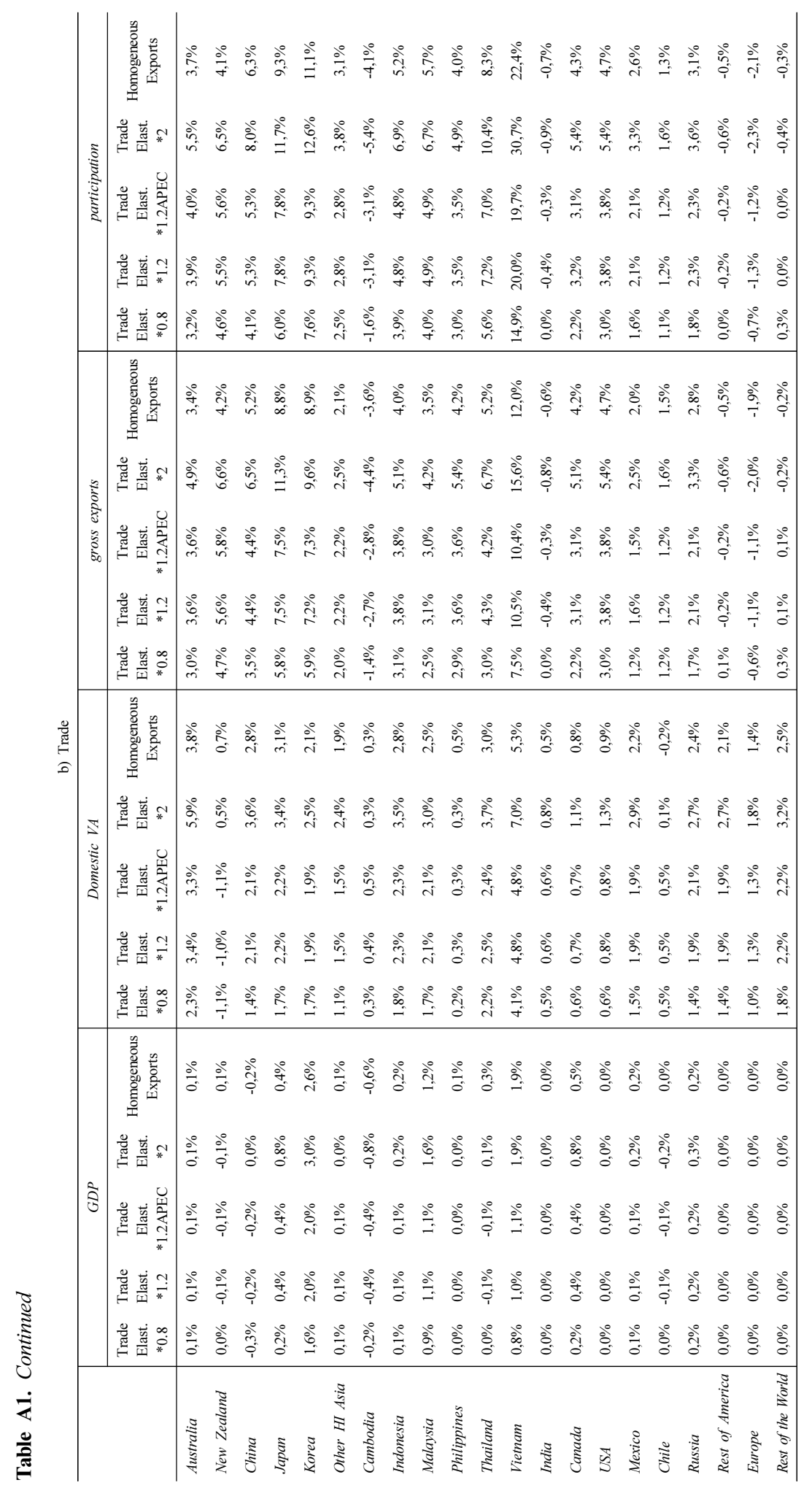




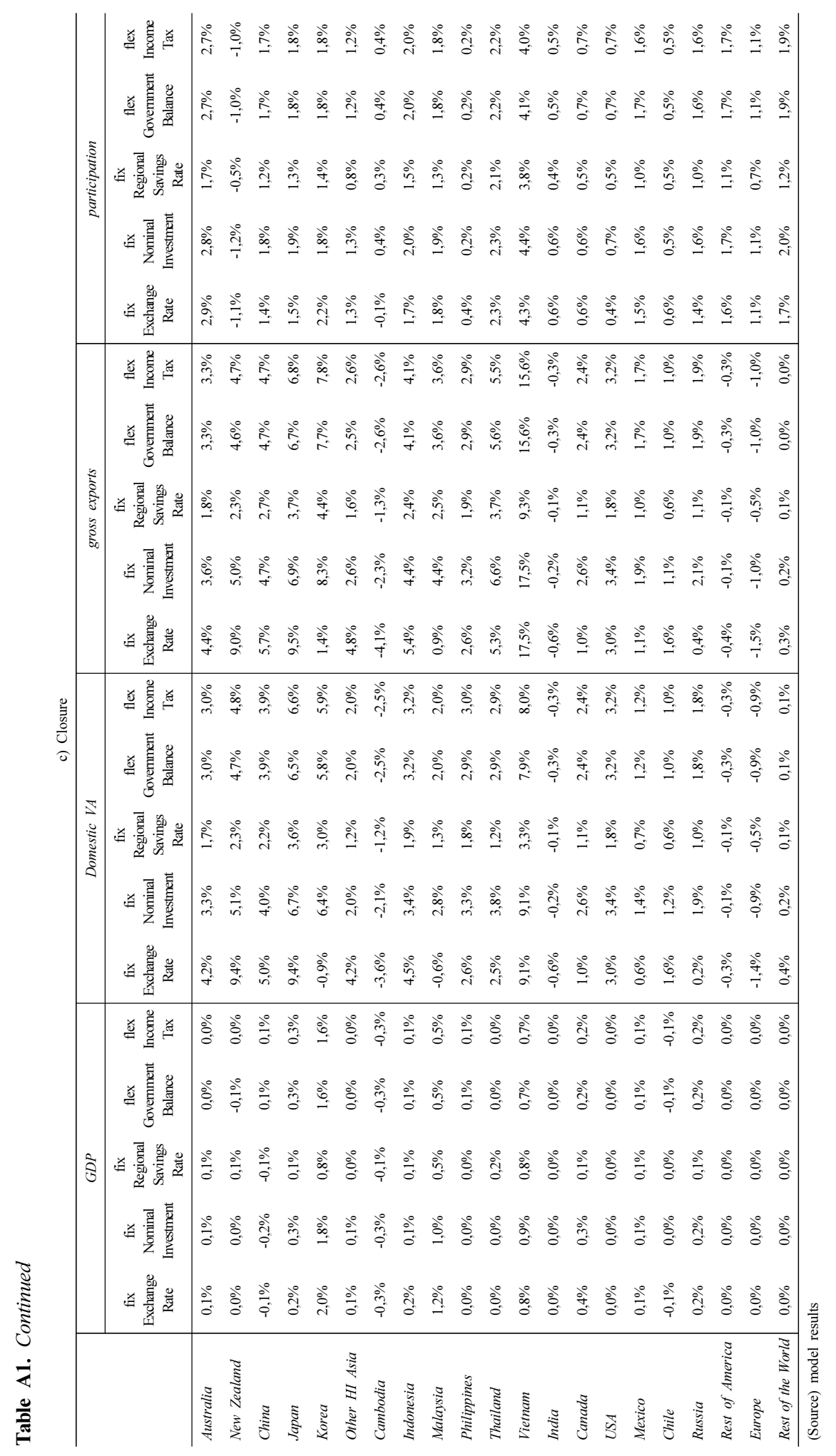

